\title{
Dakota Group in
}

Northern Front Range

Foothills, Colorado

GEOLOGIGAL SURVEY PROFESSIONAL PAPER 274-B

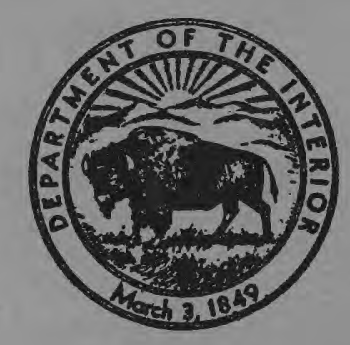




\section{Dakota Group in}

Northern Front Range

Foothills, Colorado

By KARL M. WAAGÉ

A SHORTER CONTRIBUTION TO GENERAL GEOLOGY

GEOLOGICAL SURVEY PROFESSIONAL PAPER 274-B

$A$ revised subdivision and terminology

for the Dakota group and local details

of its stratigraphy

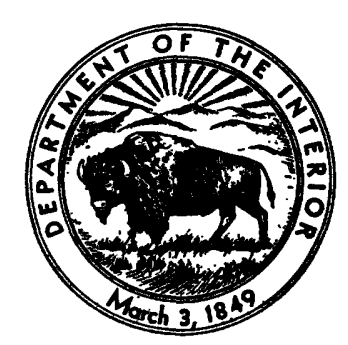




\section{UNITED STATES DEPARTMENT OF THE INTERIOR \\ Douglas McKay, Secretary \\ GEOLOGICAL SURVEY \\ W. E. Wrather, Director}

For sale by the Superintendent of Documents, U. S. Government Printing Office Washington 25, D. C. - Price 45 cents (paper cover) 


\section{CONTENTS}

Abstract

Introduction

Dakota terminology and subdivision ...............

Stratigraphy

Definition $\ldots$

Type locality of the Lytle.

Lateral variation

Contact of Lytle and Morrison formations _... _ $\quad 23$

Eldridge type locality of the Morrison.... $\quad 24$

Alameda Parkway type section........... 25

Post-Morrison warping .............. 25

Summary _.......................... 25

Contact of Lytle and South Platte formations_- $\quad 26$

Age _.................. 26

South Platte formation

Definition

Lithology _............... 27

Southern nonmarine phase _............... 28

Plainview sandstone member.......... 28
Page

Stratigraphy-Continued

South Platte formation-Continued

Southern nonmarine phase-Continued

Beds between the Plainview and Kassler sandstone members . . . . .

Kassler sandstone member.

Van Bibber shale member

First sandstone subunit and Benton contact..... 33

Lateral variation

Type locality

Intermediate phase-Boulder County

Northern marine phase.................. 38

Age. . . .

Relationship of the phases. Status of the term Dakota group Correlation of the Lytle and South Platte formations.-. 45

Evaluation of unconformities

Literature cited

Index

\section{ILLUSTRATIONS}

FIGURE 4. Distribution of the Dakota group

5. Lateral variation in the Lytle formation

6. Basal sandstone lens in the Lytle formation on Turkey Creek

7. Interpretations of the Morrison-Dakota contact

8. Contact of the Lytle and South Platte formations at Spring Canyon

9. Contact of the Lytle and South Platte formations at Eldorado Springs

10. Composite section of the South Platte formation

11. Plainview member of the South Platte formation at Plainview

12. Second shale subunit of the South Platte formation

13. Base of main clay bed of the Van Bibber member of the South Platte formation

14. Nonmarine phase of the South Platte formation on Willow Creek

15. Intermediate phase of the South Platte formation on Little Thompson Creek

16. Double hogback formed by marine phase of the South Platte formation

17. Lateral changes in the South Platte formation

18. Characteristic exposure of the Dakota group in the Denver area

19. Correlation of the Lytle and South Platte formations 


\title{
A SHORTER CONTRIBUTION TO GENERAL GEOLOGY
}

\section{DAKOTA GROUP IN NORTHERN FRONT RANGE FOOTHILLS, COLORADO}

\author{
KARL M. WAAGÉ
}

\begin{abstract}
Pre-Benton Cretaceous strata throughout eastern Colorado and adjacent areas are divisible into a lower part which consists of sandstone, conglomeratic sandstone, and variegated claystone, and an upper part which consists of dark-gray shale interbedded with units of brown-weathering sandstone. A sharp disconformity - the most pronounced lithogenetic break in the sequence of beds between the Morrison formation and the Benton shaleseparates these two parts. For the northern Front Range foothills of Colorado the name Lytle formation is applied to the lower part of the pre-Benton sequence; the upper part is named the South Platte formation. The term Dakota group is retained to include these two formations.

Lytle sediments were deposited on flood plains and are more closely related lithogenetically to the Morrison formation than to the overlying South Platte formation. The Morrison-Lytle contact is indefinite in many places because, (1) conglomeratic beds are not persistently present in the base of the Lytle and (2) the rocks in the upper part of the Morrison are similar to those in the Lytle. Both the old and new type sections of the Morrison have indefinite upper contacts. The Morrison-Lytle contact probably corresponds closely to Eldridge's MorrisonDakota contact in the Denver basin area; the prevalent belief that Eldridge included plant-bearing Dakota beds in the type locality of the Morrison is a misinterpretation of his original description.
\end{abstract}

South Platte sediments were deposited in deltaic, estuarine, littoral, and neritic environments around the spreading Cretaceous sea. The formation is largely in a nonmarine clastic phase in the southern part of the northern foothills but changes northward into a marine shale phase. Thin beds of altered volcanic ash and a single persistent marine zone facilitate correlation of the phases. Prominent local subunits are distinguished as members. All the South Platte formation except the beds at the top and base are in the zone of Inoceramus comancheanus Cragin, and the age of the entire unit is presumed to be Early Cretaceous (Albian).

In the northern Front Range foothills three distinct physical breaks occur in the sequence of beds between the undoubted Jurassic (Portlandian) part of the Morrison formation and beds of Early Cretaceous (Albian) age in the South Platte formation. Not enough fossil evidence is available to permit evaluation of these unconformities or to assign a greater time value to a particular unconformity.

The Lytle and South Platte formations can be readily correlated with their lithic equivalents in adjacent areas. The disconformity that separates them is a regional feature that lies between the Lytle sandstone and Glencairn shale members of the Purgatoire formation in southeastern Colorado. In eastern Wyoming this disconformity lies within the Cloverly formation, at or near the base of the upper sandstone member.

\section{INTRODUCTION}

Correlation and description of pre-Benton Cretaceous (Dakota) rocks in eastern Colorado is made difficult by the multiplicity of names that have been applied to them. The problem is not entirely one of confused nomenclature that can be resolved by submitting the different names to tests of precedence or usage; a basic difficulty is that none of the terminologies now in use accurately express the principal natural lithogenetic subdivisions and stratigraphic breaks that occur in the pre-Benton Cretaceous sequence throughout eastern Colorado. This report is a response to the need for a revised terminology which is suited to the broad natural subdivisions of the beds in question and yet is flexible enough to be adjusted to their local variations as revealed by detailed stratigraphic study.

Pre-Benton Cretaceous strata exposed in the Dakota hogback of the northern Front Range foothills were studied in 1951-52 during investigations of refractoryclay deposits for the U. S. Geological Survey. Previous field studies of the Dakota that contributed supplementary material include an investigation of refractory clays in the Purgatoire and Dakota formations of south-central Colorado by the Survey (Waagé, 1953) and a reconnaissance study of critical Dakota localities in Colorado and adjacent states. The reconnaissance was supported by a grant from the Shell Research Fund of the Department of Geology, Yale University.

The area of study here referred to as the northern Front Range foothills includes a narrow belt of preBenton Cretaceous exposures extending southward along the east flank of the Front Range. These expo- 
sures extend from 2 miles south of the Wyoming State line, in Larimer County, where the beds emerge from under Cenozoic cover, to the fault-terminated end of the Dakota hogback just south of Indian Creek in the Kassler quadrangle, Douglas County. The belt of outcrop (fig. 4) is continuous except for a few short
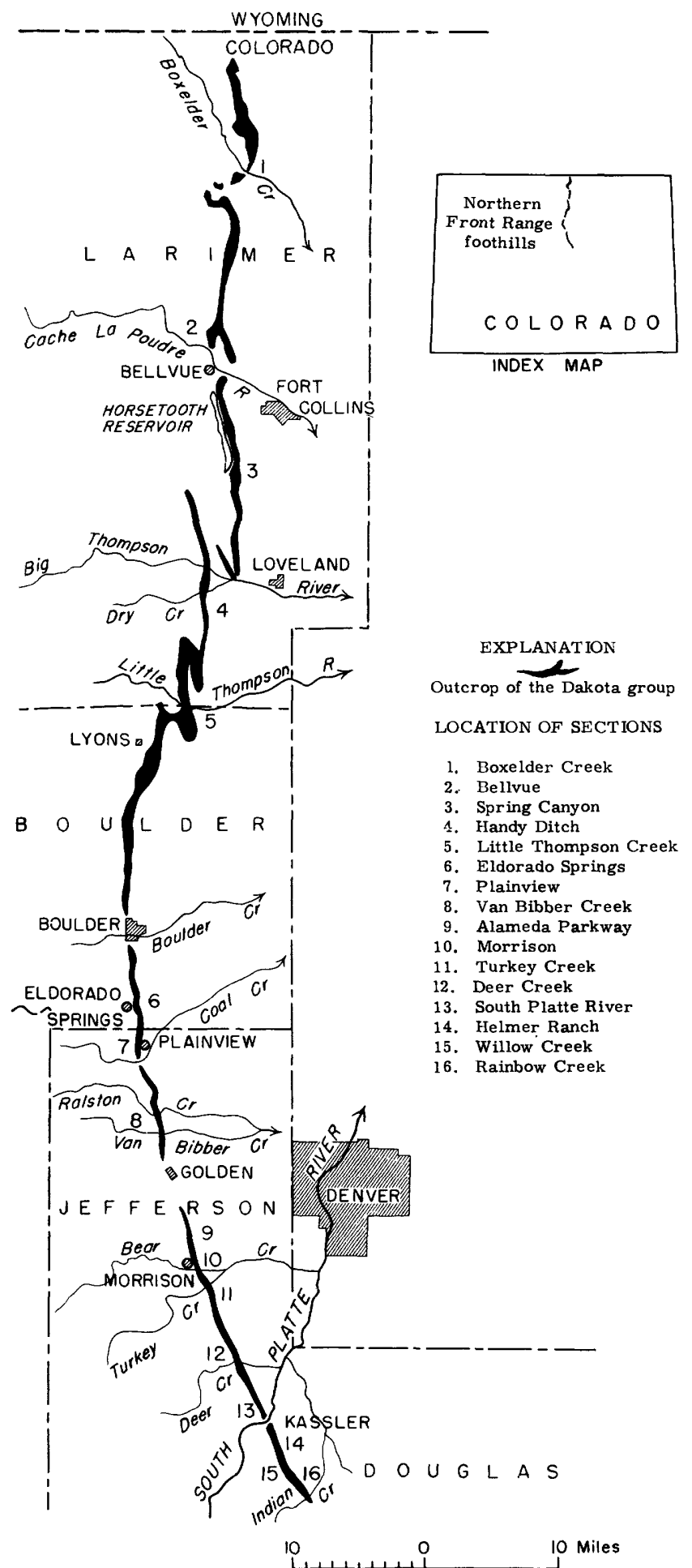

FIGURE 4.-Distribution of the Dakota group in the northern Front Range foothills, Colorado. gaps in which the beds are eliminated by faulting; the largest of these, a gap of about 3.5 miles, is at Golden. South of the end of the hogback at Indian Creek the pre-Benton Cretaceous rocks disappear by faulting for about 8 miles along the strike, and reappear in a short segment of hogback at Perry Park in the Castle Rock quadrangle.

The northern foothills area of study corresponds with the area in which Lee (1923) applied the name Dakota group to the pre-Benton Cretaceous rocks of Colorado and divided it into five informal subdivisions. The terminology presented in this report is a revision of Lee's Dakota group; consequently it is intended to apply only to the northern foothills area.

\section{DAKOTA TERMINOLOGY AND SUBDIVISION}

Pre-Benton Cretaceous strata in eastern Colorado were originally included in the Dakota group. Reports of the Hayden Survey, published between 1869 and 1878 , used this term in the same sense in which it was first applied to the basal sandy beds of the Cretaceous rocks (formation no. 1) in the type area in eastern Nebraska (Meek and Hayden, 1862, p. 419420 ). King (1878, p. 298) also adopted the term Dakota group for the reports of the 40th parallel survey, but only after Hague $(1877$, p. 39) had used the terms Dakota Cretaceous, Dakota formation, Dakota sandstone, and Dakota group interchangeably.

After the organization of the U. S. Geological Survey in 1879 successive attempts to standardize stratigraphic terminology in Survey reports (Powell, 1882, p. XLXLVII; 1890, p. 63) led to the selection of the formation as the "grand unit" for mapping. The term group gradually lost favor as a synonym for formation and was eventually reclaimed and defined (Walcott, 1903 , p. 21-27) in the broader sense in which it is understood today. Consequently the original Dakota group in publications on eastern Colorado properly became the Dakota formation, or Dakota sandstone, a change that was purely taxonomic and in no way altered the meaning of Meek and Havden's original definition.

The first attempts to subdivide the Dakota formation in eastern Colorado were informal. Gilbert (1897) distinguished an upper, fire-clay-bearing part on the economic geology sheet of the Pueblo folio. Hills was the first to emphasize a threefold division of the formation. In both the El Moro folio (Hills, 1899) and the Walsenburg folio (Hills, 1900) he notes that the Dakota formation consists of a lower porous, conglomeratic sandstone, a middle shale bed, and an upper fine-grained sandstone containing some shale. Because the middle shale was locally refractory it was 
commonly referred to as fire clay. Hills mapped this fire clay on the economic geology sheet of both folios.

Subsequent to Hills' work the threefold division of the Dakota formation in the Arkansas River valley area and elsewhere in southeastern Colorado was noted by a number of geologists. In 1905 fossils of Early Cretaceous age were discovered in the middle shale in Prowers County by Darton (1905, p. 120) and along the Purgatoire River, south of La Junta, and on Oil Creek near Canon City by Stanton (1905, p. 661-663, 666-667). Up to this time the Dakota formation in Colorado had been assumed to be Late Cretaceous (Cenomanian) in age on the basis of its fossil plants, of which the greater number were collected from sandstone in the upper part of the Dakota strata in eastern Kansas and Nebraska. Previous discovery of marine Early Cretaceous beds in Kansas, where the Dakota group underwent a taxonomic overhaul and subdivision completely separate from that in Colorado, apparently had not prepared the Colorado investigators to deal with a similar discovery. Possibly this was because the Colorado work was largely confined to quadrangles adjacent to the Rocky Mountain front and did not include Dakota terrain in southeastern Colorado, where the beds are more obviously similar to the Kansas sequence.

The recognition of the middle and, consequently, the lower part of the Dakota formation as Early Cretaceous and the continued acceptance of the top sandstone as Late Cretaceous did not bring about an immediate change in the formal terminology in Colorado, but subdivision of the Dakota on the basis of this age difference was informally expressed wherever Early Cretaceous fossils could be found in the sequence. The Early Cretaceous part of the sequence was commonly discussed separately under the heading Comanche series, or Comanche formation, (Darton, 1906, p. 25; Henderson, 1909, p. 172), in spite of the fact that it was included as a part of the "Dakota" formation or "Dakota" sandstone. The quotation marks probably indicate the dissatisfaction of the authors with this ambiguity. The first formal subdivision of the Dakota formation was made by Stose (1912) in the Apishapa quadrangle. He named the Early Cretaceous lower sandstone and middle shale of the threefold sequence the Purgatoire formation, and retained the name Dakota sandstone for the upper sandstone. Subsequently Finlay (1916), in the Colorado Springs quadrangle, named the sandstone and shale units in the Purgatoire formation the Lytle sandstone member and Glencairn shale member respectively. With the exception of the addition to the Dakota sandstone of a local refractory shale unit, the Dry Creek Canyon member (Waagé, 1953, p. 12-17), the subdivision and nomenclature have remained as designated by Stose and Finlay. The names Dakota sandstone, in its restricted sense, and Purgatoire formation have been used throughout southeastern and south-central Colorado and as far north along the Front Range foothills as Perry Park in the Castle Rock quadrangle (Richardson, 1915).

In the northern Front Range foothills very little work was done on the pre-Benton Cretaceous strata between 1912 and 1923 . No attempt was made to extend Stose's subdivisions of the original Dakota formation north of the Castle Rock quadrangle, although the presence of a similar sequence had previously been recognized in the foothills north of Boulder (Henderson, 1909 , p. 174). Lee's work in the northern foothills (Lee, 1923, p. 1-20) led to a fivefold rather than threefold subdivision of the Dakota formation in this area. His stratigraphic study of the Dakota was based on a section exposed in the Poudre Valley and Reservoir Company ditch along the north side of the Cache La Poudre River, 2 miles north of Bellvue, Larimer County. Lee called the Dakota formation the Dakota group and divided it into five informal subunits: the lower sandstone, lower shale, middle sandstone, middle shale-later renamed upper shale (Lee, 1927)-and upper sandstone. Lee used this terminology throughout the Front Range foothills north of the Castle Rock quadrangle, identifying his subunits in many measured sections and correlating them with the subdivisions of Stose and Finlay to the south and with the Wyoming terminology to the north. Later Lee (1927) elaborated on this study and extended his correlations northward into Montana. Fossils collected by Lee, and others, from the middle shale (upper shale of Lee's 1927 report) of his Dakota group were described by Reeside (1923) who recognized that the fauna was an impoverished representation of the Early Cretaceous (Washita) fauna found in the Purgatoire formation of southcentral and southeastern Colorado. No formal changes have been made in nomenclature or subdivision of Lee's Dakota group since it was proposed, and it has existed side by side with the southern classification of Stose and Finlay.

Terminologies other than that of Lee have been used in the northern Front Range foothills presumably because Lee's Dakota group is too broad a unit for detailed work and because some of its subdivisions lack lateral continuity and are difficult to apply. The Stose and Finlay terminology was used in the Denver-Golden area by Waagé (1952) but subsequent work leading to the present report has shown that it was incorrectly applied and that it is equally as unsatisfactory as Lee's in providing a logical subdivision of the pre-Benton Cretaceous strata. George (1927, p. 63-64) called the 
Early Cretaceous rocks throughout eastern Colorado the Purgatoire and incorrectly used the names Lakota and Fuson in the northern foothills for members of the Purgatoire that he considered equivalent, respectively, to Finlay's Lytle and Glencairn members of the Purgatoire in the Colorado Springs area. This unfortunate usage, based on incorrect correlation with the Black Hills area (fig. 19), is still used in Colorado by some workers. Other workers have extended the CloverlyThermopolis-Muddy terminology southward from Wyoming, and some still use the term Dakota formation in the sense in which it was used in early reports of the Geological Survey.

Inasmuch as Lee's terminology is the only one based on a careful stratigraphic study, it is certainly the most acceptable and the most useful of the existing possibilities. The Geological Survey (Wilmarth, 1938, p. 566) provirionally accepted Lee's Dakota group for northern Colorado with the condition that

If the Purgatoire proves to be present in the Bellevue section it will be removed from the Dakota group of W. T. Lee.

Several sources of confusion in the usa;re of preBenton Cretaceous terminology are apparint in the history of subdivision and nomenclature outlined in the preceding paragraphs. The first source was the taxonomic change from the use of the terms formation and group as synonyms to their use as terms for separate ranks of rock units. A more critical source was the tendency to separate the Early Cretaceous from the Late Cretaceous parts of the pre-Benton Cretaceous sequence, a tendency that influenced, and is reflected in, Stose's formal subdivision of the old Dakota formation in southeastern Colorado. The use of age as a criterion for the subdivision of rock units, a practice at the root of many nomenclatural problems, can lead only to confusion in correlation and to ambiguity in terminology when applied to complex transgressive deposits like the pre-Benton Cretaceous sequence. Much of the confusion associated with the name Dakota stems from this cause. An unfortunate nomenclatural practice, that of retaining the name Dakota for the Late Cretaceous part of the sequence in those areas where Early Cretaceous rocks can be identified and separated, has served to crystallize the confusion. This practice has been applied in Kansas and in Colorado, making it impossible to use the name Dakota in a single sense for physical correlation between areas in which Early Cretaceous strata are separated from the Dakota and areas in which the occurrence of Early Cretaceous rocks has not been sufficiently well established to permit their separation from the Dakota.

Introduction of terminologies from other areas is a recent source of confusion in the Colorado pre-Benton
Cretaceous classification. It is understandable, when one considers the confused state of the local terminology and the reluctance of workers to use the name Dakota in any sense because of its ambiguity, but the practice is untrustworthy in light of our lack of knowledge about the details of regional Dakota stratigraphy. The continued use of the rather obvious incorrect correlation of the Glencairn member of the Purgatoire formation with the Fuson shale illustrates the hazard of using a foreign nomenclature to circumvent the inadequacies of the native nomenclature. It has become increasingly obvious, as work on the Dakota has progressed, that neither the local classifications proposed for the pre-Benton Cretaceous sequence in eastern Colorado nor the foreign classifications are adapted to the natural lithogenetic subdivision that characterizes the sequence throughout much of the western interior. This natural subdivision either has been overlooked or has been effectively obscured by the unquestioned acceptance of previous classifications.

\section{STRATIGRAPHY}

Inasmuch as none of the classifications applied to the pre-Benton Cretaceous sequence in Colorado accurately express its principal lithogenetic subunits and stratigraphic breaks, all previous systems of nomenclature are excluded from the following discussion in order to present the general stratigraphic features of the sequence without the bias that such systems impose.

The most noticeable stratigraphic feature in the sequence of Dakota strata lying between the Morrison formation and the Benton, or Graneros, shale in eastern Colorado is its divisibility into two distinctive parts. The lower part consists of irregular lenses of light-gray to gray-white, commonly porous sandstone, and conglomeratic sandstone which are irregularly interbedded with variegated claystone similar to that in the underlying Morrison formation. Weathered outcrops of the sandstone are highly variable in color but light values of buff and gray predominate, and pink and yellow staining is common. This lower part of the sequence is typified by its variability, both in the relative amounts of sandstone to variegated claystone and in the irregular thickness and distribution of the sandstone lenses.

Contrary to common belief, the base of the lower part of the sequence is not consistently marked by a conglomerate bed. Where the lower part is a single massive unit composed chiefly of sandstone and conglomerate, an obvious physical break occurs between it and the Morrison formation. At other localities the lower part of the sequence consists of alternating lenses 
of sandstone and variegated claystone similar to the upper part of the Morrison and there is no obvious unconformity between the units.

The upper part of the sequence consists of sandstone units that weather buff and brown and alternate with units of dark-gray to black shale and siltstone. The sandstone beds are dominantly fine grained, tabular to massive, cross laminated, and less porous and more resistant than those in the lower part of the sequence. The intervening dark-colored shale units are laminated, commonly silty, and contain thin layers of altered volcanic ash. Although somewhat variable in lithology and thickness, the changes in the sandstone and shale units are gradual, lateral changes in facies, and the upper part of the sequence as a whole presents a regularity in its succession and a continuity of its parts that contrasts markedly with the lenticularity of the lower part of the sequence.

The contact between the upper and lower parts of the sequence is a persistent disconformity marking the abrupt change from the variegated claystone and graywhite sandstone below to the black shale and brownweathering sandstone above. The disconformity is a planed surface on which rests, in many places, a thin conglomerate or conglomeratic sandstone. Beneath the disconformity the upper few feet of the lower part of the sequence commonly consists of weathered sandy clay or claystone containing local concentrations of iron oxide. The disconformity is the most obvious physical break in the section between the Morrison formation and the Benton shale; it can be traced throughout eastern Colorado and into adjacent States.

The interpretation of the gross twofold lithic division within the pre-Benton Cretaceous sequence is fairly evident. The lower part of the sequence consists of flood-plain deposits more closely related lithogenetically to the underlying Morrison formation than to the upper part of the pre-Benton sequence. Probably much of the sediment in the lower part of the sequence is locally derived from the Morrison. The disconformity separating the lower from the upper part of the sequence is a transgressive feature affording the first evidence of an invading Cretaceous sea. The initial deposits above the disconformity are chiefly fresh- and brackish-water beds presumably deposited in local deltas or in bodies of water impounded along the coastal plain by the rise in sea level. The time value of the disconformity cannot be accurately assessed at any given locality because of the lack of diagnostic fossils, but it was sufficiently long in many places to allow leaching of the top of the lower part of the sequence.

The upper part of the sequence is a record of both 332778-55-2 2 local and regional fluctuations in strand line. In some places, presumably the larger deltaic areas, the sequence is predominantly nonmarine, in other places it is predominantly marine or estuarine: everywhere it is a complex unit recording local conditions at or near the strand line from the initial impounding of coastal-plain drainage until marine conditions prevailed.

The upper and lower parts of the pre-Benton Cretaceous sequence and the disconformity that separates them are regional features useful for physical correlation throughout much of the interior region. In the northern Front Range foothills of Colorado, this twofold lithogenetic division affords a logical basis for separating the sequence into formational units. The name Lytle formation is here applied to the lower unit of sandstone, conglomeratic sandstone, and variegated clay, and the name South Platte formation is given to the upper unit of alternating sandstone and dark-colored shale beds. The term Dakota group is retained to include these two formations.

\section{LYTLE FORMATION}

DEFINITION

The beds of sandstone, conglomeratic sandstone, and variegated claystone that make up the lower part of the pre-Benton Cretaceous sequence are correlated here with the Lytle sandstone member of the Purgatoire formation in south-central Colorado and the name Lytle, raised to the rank of formation, is applied to them throughout the northern Front Range foothills.

Finlay (1916, p. 7-8) gave the name Lytle sandstone member to the lower sandy part of the Purgatoire formation in the Colorado Springs quadrangle, noting that it consists of light-colored sandstone, pebbly beds, and "scattered lenses of greenish or reddish clay near the top;" he also mentions that the overlying Glencairn shale member is "rather sharply separated from the Lytle member." Finlay did not recognize the disconformity separating the two lithogenetically dis tinct parts of the pre-Benton sequence but it is obvious from his descriptions that he intended to separate his Glencairn and Lytle members at this lithic change. Waagé $(1953$, p. 7-9, 27) traced the members southward into south-central Colorado and used the disconformity as the contact between them. Correlation of the Lytle sandstone member of the Colorado Springs area with the lower part of the pre-Benton Cretaceous sequence in the northern foothills is clear cut inasmuch as the disconformity occurs in both the northern and southern Front Range foothills. Furthermore the beds beneath it are lithologically identical and show the same stratigraphic relations with the underlying Morrison formation. 
TYPE LOCALITY OF THE LYTLE

Finlay took the name Lytle from a small settlement of a few homes along Turkey Creek in the southwestern part of the old Colorado Springs 15-minute quadrangle. Today the locality is marked by the Lytle School, situated along Lytle Road just south of Turkey Creek in the $\mathrm{SW}^{1 / 4} \mathrm{NW}^{1 / 4}$ sec. 2 , T. 17 S., R. 67 W., Timber Mountain quadrangle. The following section was measured at the typical exposure northeast of the school on the west-facing scarp of the hogback between Turkey Creek and Little Turkey Creek.

\section{Description}

Purgatoire formation (in part).

Glencairn shale member (in part):

Sandstone, fine- to coarse-grained, tabular,

Foet cross-laminated; weathers brown ......... 3. 0-7. 0

Disconformity.

Lytle sandstone member:

Sandstone, fine-grained, argillaceous, soft; weathers white, with local yellow stain; grades into unit below

Sandstone, fine- to medium-grained, massive, cross-laminated, with seattered irregular layers of conglomeratic sandstone; weathers gray, light gray, and yellowish gray _... 47. 0-? Remainder of section obseured by slope wash.

Dinosaur bone fragments found in the slope wash 90-100 feet below the top of the type section suggest that the Lytle sandstone member is less than 100 feet thick at this place. Finlay gives an average thickness of 145 feet for the Lytle in the Colorado Springs area but this figure is excessive. No clear-cut contact between the Lytle member and the Morrison formation was seen in the type area, but conglomeratic sandstone ledges that presumably mark the base of the member crop out locally between 50 and 70 feet below the top of the unit.

\section{LATERAL VARIATION}

In the northern foothills abrupt lateral variation in the local dominance of its sandstone or claystone fraction is characteristic of the Lytle formation. At one extreme the Lytle consists almost entirely of sandstone and conglomerate and resembles its more consistently arenaceous southern equivalent, the Lytle sandstone member of the Purgatoire formation. At the other extreme the Lytle lacks conglomeratic beds and consists of approximately equal amounts of fine- to medium-grained sandstone and variegated claystone distributed in alternating lenses. Generalized graphic sections of the Lytle formation illustrating its variable lithic content and thickness are shown in figure 5 . Two of these sections are given in more detail.

A dominantly sandy section of the Lytle formation is exposed in the road cut along Colorado Route 186 on the south side of the dam across Spring Canyon, Horsetooth Reservoir, SE1/4 sec. 32, T. 7 N., R. 69 W., Larimer County.

\section{Description}

South Platte formation.

Disconformity.

Lytle formation:

Feet

8. Claystone, light-gray with pink and yellow stain, sandy; grades imperceptibly into unit below ..... 1. 0-4. 0

7. Sandstone, fine-grained, massive, cross-laminated; weathers yellowish gray to buff with local pink and light-purple staining - -

6. Claystone, gravish-green with red and yellow stain in uppermost foot, silty ..........

5. Sandstone, argillaceous, and claystone, sandy; weathers with red, pink, and yellow stain . -

4. Sandstone, light-gray with pink to yellow cast, fine-grained, cross-laminated, with thin irregular interbeds and lenses of greenishgray silty claystone. Clay-pellet conglomeratic layers throughout, thickest at base.-

3 . Sandstone, as in unit 4 but fine- to coarsegrained with a few thin lenses of small chert and quartzite pebbles. Few lenses of claystone and a 2.2-foot bed of claypellet conglomerate 8 feet from top......-

2. Sandstone and conglomerate. Upper 3-4 feet are chert and quartzite-pebble conglomerate; remainder partially obscured by wash, apparently massive, cross-laminated, friable sandstone and conglomeratic sandstone . . . . . . . . . . . . .

Unconformity.

Morrison formation:

1. Clay and claystone, variegated, silty, upper 2 feet yellow, underlain by 4 -foot zone of purplish-red claystone which grades downward through about 3 -foot zone of maroon and bluish-purple to typical greenish-gray claystones of the Morrison

12. $0 \pm$

In the scarp face of the Dakota hogback north of Deer Creek in $\mathrm{SE}_{1 / 4}^{1 / 1} \mathrm{NE}_{4}^{1 / 4} \mathrm{SE}_{1 / 4}^{1 / 2 e c}$. 5, T. $6 \mathrm{~S}, \mathrm{R} ., 69 \mathrm{~W}$, Indian Hills quadrangle, the Lytle consists of alternating units of sandstone and claystone.

\section{Description}

South Platte formation.

Disconformity.

Lytle formation:

9. Claystone, gray containing local pink stain, sandy, some zones argillaceous sandstone _... $0.3-1.0$

8. Sandstone, medium- to coarse-grained and conglomeratic, massive, lenticular, locally cliff forming; weathers light gray and light buff. Conglomerate chiefly in lower 10 feet ....... Unconformity.

7. Siltstone, light-gray and greenish-gray, red mottling in lower 5 feet, some scattered lenses of silty claystone and some argillaceous sandstone 
DAKOTA GROUP IN NORTHERN FRONT RANGE FOOTHILLS, COLORADO

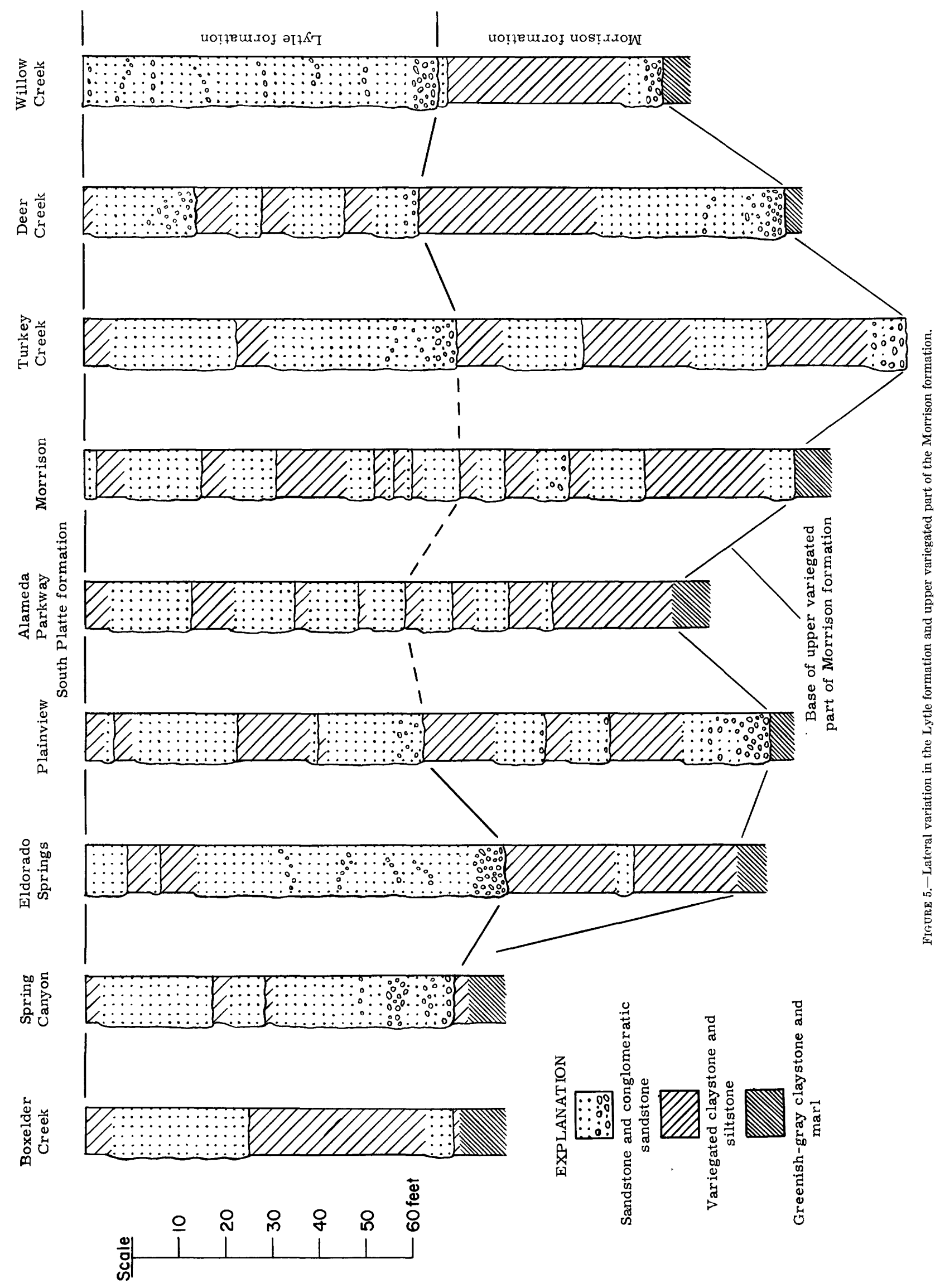


Lytle formation-Continued

6. Sandstone, fine- to medium-grained, massive, ferruginous specks throughout; weathers orange brown; 0.4-foot zone of argillaceous siltstone 3.0 feet from top. .............. Unconformity.

5. Claystone, silty, and argillaceous siltstone, chiefly red, some gray and greenish gray. Contains thin bed of hard light-gray sandstone 2.0 feet above base

4. Sandstone, fine- to medium-grained, massive, ranges from 4 to 15 feet in thickness within 100 feet along strike; weathers light gray; local silty zones at base and top.......... Unconformity.

3. Claystone, red, silty, some green mottling at top and base. Contains rare polished chert pebbles ("gastroliths") as much as 3 inches in long diameter.

2. Sandstone, medium- to coarse-grained; weathers light gray to buff; some conglomeratic zones of small chert and quartzite pebbles.

Unconformity.

Morrison formation (in part):

1. Claystone, silty with interbeds of argillaceous siltstone, chiefly green and gray with silty zones weathering yellowish gray, minor red mottling in lower part

Distribution of conglomeratic lenses along the Lytle outcrop in the northern foothills is erratic and, contrary to common belief, there is no persistent basal conglomerate marking the Morrison-Lytle contact. Less than half the Lytle outcrop between Indian Creek

6. 5 and Boulder, where the formation was mapped at a scale of $1: 10,000$, contains prominent conglomeratic units and as much as a third of this outcrop lacks conglomeratic beds (fig. 6).

No persistent mappable subdivisions of the Lytle formation are recognized in the northern foothills. In parts of Larimer County and at a few scattered localities to the south, the beds in the upper 5-15 feet of the Lytle are commonly variegated claystone and the beds below are sandstone and conglomeratic sandstone. The Bellvue section, chosen by Lee $(1923$, p. 4) as the type for his Dakota group, shows this arrangement of

6. 5 beds, and Lee recognized two separate subdivisions, his lower sandstone and lower shale, to include them.

8. 5 This arrangement is not persistent along the Colorado

. 0 Front Range, where it is interrupted too repeatedly along the strike to afford a valid or practical basis for subdivision. Moreover, Lee did not notice the disconformity and included black shale above it as well as variegated claystone below it in his lower shale unit. The variegated shale at the top of the Lytle formation in the Bellvue section is 15 feet thick, about its maximum thickness for the northern foothills. Elsewhere

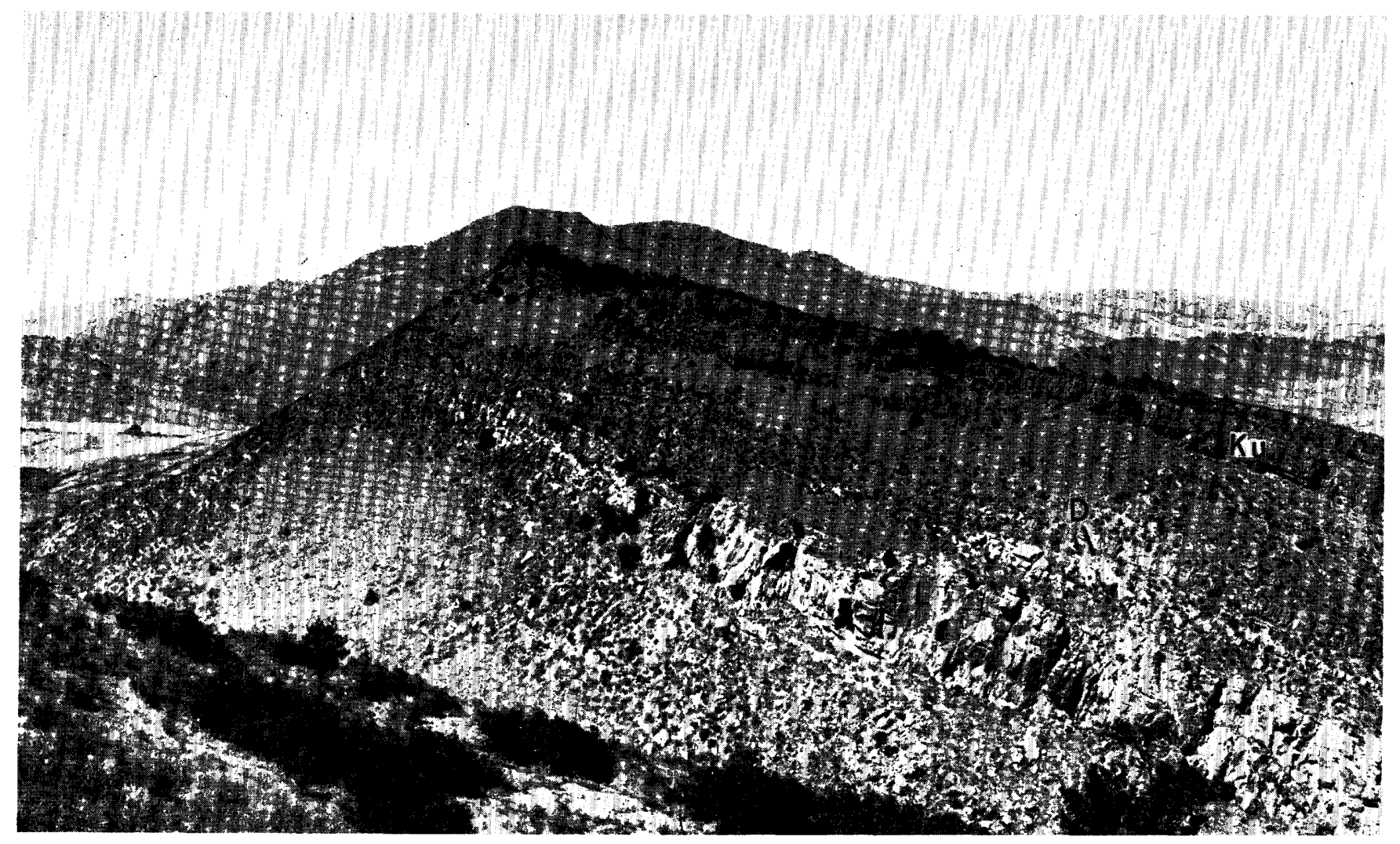

FIgure 6.-Basal sandstone lens $(L)$ in the Lytle formation thins out along strike on north wall of Turkey Creek gap, Morrison quadrangle. $D$, contact of Lytle and South Platte formations; $K u$, combined Kassler sandstone member and upper sandstone subunit. 
it is rarely more than 10 feet thick and at many places it is absent.

\section{CONTACT OF LYTLE AND MORRISON FORMATIONS}

The position of the Morrison-Lytle contact cannot be located at many places because of the lithic similarity between the Lytle formation and the uppermost beds of the Morrison formation. Where the Lytle formation lacks a conglomeratic basal lens, or where it consists of several weakly conglomeratic lenses separated by variegated claystone, no single, obvious physical break separates the two formations. Even where the Lytle is dominantly conglomeratic the position of the contact may be in question because of the presence of similar conglomeratic lenses in the upper part of the Morrision (fig. 5). A thorough discussion of this problem is not within the scope of this paper, but a brief review of it is pertinent for an understanding of what the Lytle formation is meant to include.

Leroy (1946, p. 59) has recognized the following six informal subdivisions in the new type section of the Morrison formation (Waldschmidt and Leroy, 1944) along West Alameda Parkway 2 miles north of the original type section at Morrison.

$$
\begin{aligned}
& \quad \text { Units } \\
& \text { Sandstone and shale } \\
& \text { Red shale } \\
& \text { Gray shale and sandstone } \\
& \text { Gray clay and limestone } \\
& \text { Gray and red shale } \\
& \text { Basal sandstone }
\end{aligned}
$$

Not all these units can be identified away from the Alameda Parkway section, and a more generalized subdivision is desirable for discussion of the Morrison in the northern Front Range foothills. Leroy's two middle units make up the most characteristic part of the Morrison, a light-gray to greenish-gray marl and claystone with intercalated thin limestone beds and a few thin calcareous sandstone lenses. This zone occupies 100 feet or more of the Morrison throughout the Front Range foothills and includes the famous dinosaur-bearing beds as well as beds containing the Morrison fresh-water molluscan fauna (Yen, 1952, p. 28). Above these undoubted Morrison strata the sequence locally consists of dominantly red, variegated, silty claystone with lenses of sandstone, the whole too variable laterally to permit division into useful subunits. At many localities discontinuous lenses of conglomerate occur approximately at the contact of the dominantly red variegated beds and the underlying greenish-gray beds. The Lytle formation is similar to the upper dominantly red variegated zone of the Morrison and differs only in its local predominance of sandstone and conglomeratic sandstone, in the somewhat lighter hues of its variegated beds, and in the composition of its conglomerates. Conglomerates of the Lytle are dominantly chert and quartzite-pebble conglomerates with interstitial sand; locally they are cemented by chert. Conglomerates at the base of the upper Morrison are also made up of chert and quartzite pebbles but have considerable interstitial clay commonly peppered with ferruginous specks.

Three principal types of stratigraphic relationships are found at the Morrison-Lytle contact along the Front Range. The most obvious contact is formed where a thick, conglomeratic sandstone lens of the Lytle rests unconformably on the greenish-gray claystone and marl of undoubted Morrison strata. Contacts of this kind are most common north of the latitude of Lyons; the Spring Canyon section (fig. 5) exposed in the road cut at the Spring Canyon dam site on Horsetooth Reservoir is an example. At most exposures where conglomeratic sandstone of the Lytle rests on the greenish-gray Morrison a thin zone of purple or deep-maroon clay from 1 to 3 feet thick underlies the contact.

A second type of contact is formed by a basal conglomeratic sandstone lens in the Lytle resting with obvious unconformity on some part of the dominantly red variegated clay and sandstone in the upper Morrison. Exposures of this type of contact can be found on the scarp of the hogback south of E]dorado Springs (fig. 5), in Turkey Creek gap south of Morrison (fig. 5), on the scarp of the hogback north of Deer Creek (fig. 5) and at other places throughout the hogback between Boulder and Indian Creek.

The third type of contact is a variation of the second type in which the contact itself is obscure because the entire sequence of beds between the disconformity at the top of the Lytle and the greenish-gray claystones of undoubted Morrison consists of alternating lenses of sandstone, or conglomeratic sandstone, and variegated claystone. Sequences of this type occur where the upper Morrison is sandier than usual and the Lytle is more argillaceous than usual and lacks a conspicuous conglomeratic lens at its base. Indefinite contacts can be seen in the Denver and Salt Lake Railroad cut at Plainview (fig. 5), in Eldridge's type Morrison exposure at Morrison (fig. 5), and in the new type Morrison exposure in the Alameda Parkway road cut (fig. 5). At Plainview, five massive sandstone units, four of them conglomeratic to varying degrees, lie between the disconformity at the top of the Lytle and the greenish-gray Morrison. Lateral tracing from the Eldorado Springs section, where the base of the Lytle is clear cut, indicates that the second lens from the top in the Plainview cut is in the correct relative position to be the basal lens of the Lytle. 


\section{ELDRIDGE TYPE LOCALITY OF THE MORRISON}

An indefinite contact between the Morrison and Lytle formations in both the old and new type sections of the Morrison raises the question of where its upper contact was originally placed. Eldridge's (1896, p. 60-62) definition of the Morrison did not include a measured section, and his description of the upper limit of the formation has been interpreted in different ways.

Lee's (1920) idea that Eldridge included plantbearing beds of the Dakota in his original definition of the Morrison has been accepted by many geologists (Stokes, 1944, p. 954-956; Reeside, 1952, p. 22); others (Waldschmidt and LeRoy, 1944, p. 1100) contend that Lee misinterpreted Eldridge and that the MorrisonDakota contact as defined by Eldridge is acceptable. Lee's (1920, p. 183-184) interpretation of Eldridge's Morrison-Dakota contact was based on the word of G. L. Cannon, a Colorado geologist who assisted in the fieldwork for the Denver basin monograph. According to Lee, Cannon intimated that Eldridge placed the contact in question at the base of the ledge-forming sandstone capping the Dakota hogback at Morrison, a horizon above the middle of the gray shale-bearing part of the Dakota group in this area. In terms of the nomenclature introduced in the present report this horizon is the base of the Kassler sandstone member of the South Platte formation (fig. 7).

Eldridge's original description of the Morrison not only fails to offer evidence in favor of Lee's interpreta-

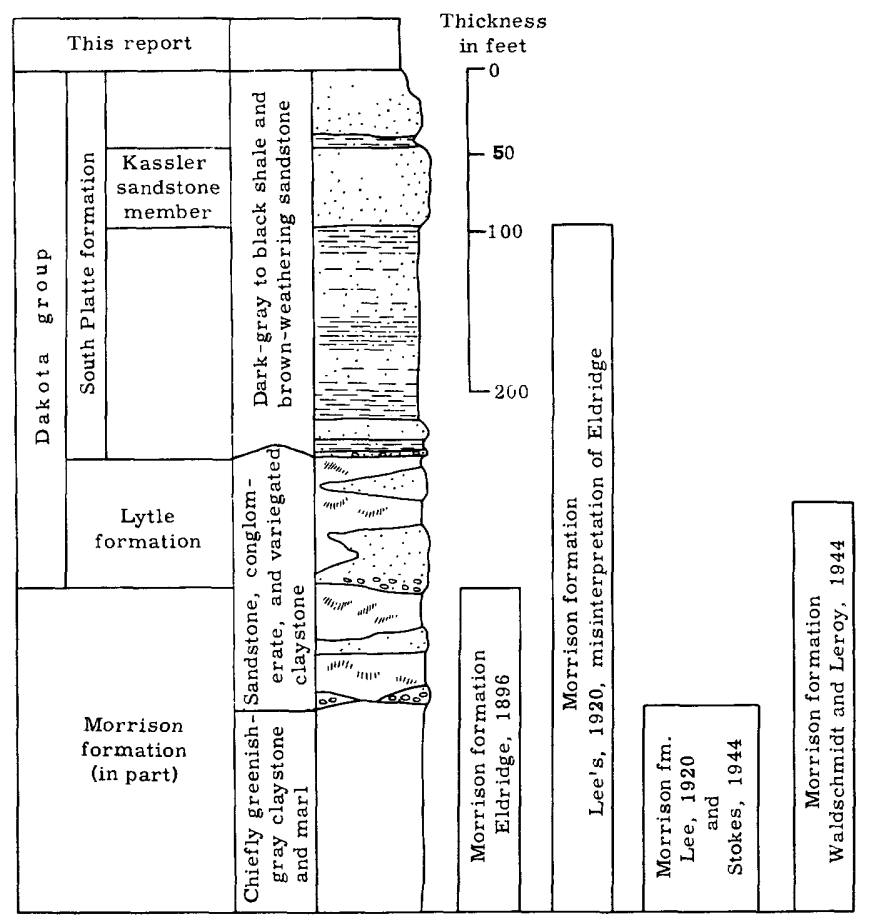
FIGURE 7.-Several interpretations of the contact between the Morrison formation
and the Dakota group in the Denver area. tion, but contains lithic descriptions and thickness figures that serve to refute Lee's interpretation. Eldridge states $(1896$, p. 61$)$ that the "upper third" of the Morrison is "a succession of sandstones and marls" which includes a conglomeratic sandstone at the base and, above it, sandstone interbedded with shale. He specifically describes the shale as "similar to those comprising the bulk of the Jura," in other words, variegated shale, not gray or black shale. A comparison of the relative thicknesses of the units described by Eldridge further demonstrates that he could not have included any of the plant-bearing Dakota with his type Morrison. Eldridge gives an average thickness of 200 feet for the Morrison; consequently the part of the formation he refers to as the "upper third" can be expected to be about 60 or 70 feet thick. In the section measured by the writer at Morrison, 65 feet of variegated clay and sandstone, including a weakly conglomeratic sandstone, lie between the dominantly greenish-gray Morrison claystones and the probable base of the Lytle formation. Actually the Morrison is about 270 feet thick at the type locality, not 200 , but even a third of this larger figure would not make the upper part of the Morrison more than 100 feet thick. Yet, if Lee's interpretation is applied to the section measured at Morrison, the "upper third" of the Morrison is 228 feet thick, and the formation as a whole is between 350 and 400 feet thick, or about double Eldridge's figure. By Lee's interpretation the overlying Dakota, said by Eldridge to be between 225 and 300 feet thick, is only 78 feet thick. Certainly Eldridge would have mentioned local deviations of this magnitude in the thickness of his formations had they existed.

Lee (1920) revised Eldridge's type Morrison section, placing the upper contact under the so-called Saurian sandstone which marked the base of the upper third of Eldridge's Morrison. His stated reason for this revision was that "No obvious break was found in the section between the plant horizon and the Saurian conglomerate" (Lee, 1920, p. 185). In the Turkey Creek section 1.8 miles south of the type Morrison, Lee (1927, p. 28) placed his Morrison-Dakota contact at the base of the Lytle, apparently unaware that the break he had chosen as the contact at Morrison lay some 98 feet stratigraphically below. Throughout the foothills region Lee (1927) confused the two conglomeratic zones in question and consistently placed his Morrison-Dakota contact at the base of the most obvious conglomerate zone, apparently unaware that more than one such zone existed. This is understandable when one recalls that Lee's study of the Dakota group along the Front Range was made with reference to the "type section" of his Dakota group at Bellvue 
where the entire upper variegated part of the Morrison is absent and the Lytle rests directly on the greenishgray marl and claystone of the Morrison.

An examination of the Morrison type section with its lack of conglomeratic beds and indefinite MorrisonLytle contact indicates that Eldridge based his description of the Morrison on its aspect throughout the Denver basin area rather than at Morrison, Colo. Had he presented a measured section of the type it would have been difficult for him to indicate his Morrison-Dakota contact because of the absence or obscurity of the basal conglomerate of the Dakota. Two clues to Eldridge's conception of the position of the Morrison-Dakota contact are implicit in his description of these two formations. The first is his recognition of two horizons at which conglomeratic lenses are commonly located, one at the base of his Dakota and one at the base of the upper third of his Morrison. The second is the presence of variegated clay, rather than black shale, in the sandy strata between these two conglomeratic zones. The pattern of two conglomeratic zones separated by beds containing variegated clay corresponds closely to the sequence including the basal conglomerate of the Lytle and the underlying variegated beds of the upper part of the Morrison with their discontinuous basal conglomeratic zone. Consequently, it is most likely that the Morrison-Lytle contact of the present report corresponds to Eldridge's Morrison-Dakota contact.

\section{ALAMEDA PARKWAY TYPE SECTION}

Waldschmidt and LeRoy (1944, p. 1100) in recommending a new type section for the Morrison formation recognize that Lee (1920) misinterpreted Eldridge's Morrison-Dakota boundary. Nevertheless they believe that Lee corrected this error in a subsequent paper (Lee, 1927), for they state that

... the Morrison lies with apparent disconformity below the conglomeratic phase of the Dakota as it was originally defined by Fldridge (1896, p. 60-62) and Lee (1927, p. 28) . .

Lee's 1927 work offers a somewhat more accurate section of the type Morrison than the estimated section presented in his 1920 work, but the two sections are obviously much the same and can be matched to show that Lee did not change the position of his MorrisonDakota contact in his 1927 work. Consequently the top of the Morrison as defined by Eldridge (1896, p. $60-62)$ and as redefined by Lee $(1927$, p. 28) is in different stratigraphic positions, Lee's being at the base of the conglomeratic zone in the upper third of Eldridge's Morrison formation.

The new type section of the Morrison formation along west Alameda Parkway is better exposed than Eldridge's type section at Morrison but the upper contact is equally obscure. None of the many thin sandstone lenses between the disconformity at the top of the Lytle formation and the greenish-gray claystones of the Morrison contain pebbles of chert and quartzite. Waldschmidt and LeRoy have chosen the base of the uppermost massive sandstone lens in the Lytle as the top of their Morrison, but this ledge thins out into variegated claystone a short distance north of the road cut. The statement (Waldschmidt and LeRoy, 1944, p. 1100) that this sandstone is conglomeratic in the Alameda exposure should be modified inasmuch as the conglomerate consists of scattered clay pellets but lacks the chert and quartzite pebbles so typical of the "conglomeratic phase of the Dakota." Chert and quartzite pebble conglomeratic sandstones, presumably at the base of the Lytle, crop out locally along the hogback north of the Parkway and, when followed laterally toward the road cut, apparently grade into nonconglomeratic sandstone that lies between 35 and 55 feet below the Morrison-Dakota contact chosen by Waldschmidt and LeRoy. Slope wash prevents continuous lateral tracing from the conglomeratic outcrops so that the exact contact of the Morrison and Lytle formations in the Alameda type section remains in doubt.

\section{POST-MORRISON WARPING}

The contact of the Lytle formation with both the greenish-gray part of the Morrison formation and its upper variegated sandy part suggests either local, deep, pre-Lytle channeling, slight angular unconformity, or a combination of the two. Detection of discordance in bedding at the contact is impossible because the sandstone bodies on either side are irregularly lenticular and crossbedded. In the Canon City area and to the south in the Wet Mountains the overlap of older formations by the Lytle sandstone member of the Purgatoire formation (or Dakota) has been noted by a number of authors. Although some of these occurrences need to be corroborated by further study, there is evidence that the Morrison is locally overlapped by the Lytle. In western Oklahoma Stovall (1943, p. 60) has demonstrated gentle angular unconformity between the Morrison and Purgatoire. For the northern foothills of the Front Range all that can be said with certainty is that the Lytle rests unconformably on different parts of the Morrison which are stratigraphically as much as 100 feet apart. The fact that this crosscutting of the underlying Morrison takes place gradually along the strike rather than in abrupt local channels strongly suggests slight angular unconformity.

\section{SUMMARY}

The beds between the disconformity that marks the top of the Lytle formation and the greenish-gray clay- 
stones of undoubted Morrison are highly lenticular and variable in thickness and lithology. They contain two horizons at which conglomeratic lenses are locally common. The upper one of these has the thicker and more persistent conglomeratic lenses and the unconformity at their base is taken as the Morrison-Lytle contact. As far as can be inferred from the original description of the Morrison formation, this contact corresponds to the Morrison-Dakota contact of Eldridge. Slight angular unconformity is indicated at the base of the Lytle formation in additon to local channeling. The conglomeratic lenses of the Lytle are generally the more resistant and consequently are more prominent on the outcrop. Where they are absent, or nonresistant, or separated into many benches by variegated claystone, the Morrison-Lytle contact is indefinite. Throughout most of the northern foothills the local conglomeratic lenses at the base of the Lytle crop out near enough to one another so that the position of the Morrison-Lytle contact can be interpolated between them. Where it is not possible to recognize the contact over a large area, it is expedient to map the Lytle with the Morrison as an undifferentiated unit.

\section{CONTACT OF LYTLE AND SOUTH PLATTE FORMATIONS}

Beneath the disconformity that marks the top of the Lytle formation the beds appear to be leached. Yellow to white, soft clay, argillaceous siltstone, and finegrained sandstone with ferruginous panlike concretionary layers form a distinctive zone that is helpful in locating the disconformity on the outcrop. Tests made of this material where it is chiefly clay or claystone show that the alumina content is high just beneath the contact but decreases abruptly downward. Locally the clay just beneath the contact qualifies as a high heat duty refractory clay, but the clay bodies are too thin and discontinuous to be mined. Clay below this zone is generally light shades of red and green and is well below refractory grade. At a very few places the leached zone is thin or entirely lacking, but the sharp contact is nonetheless evident because of the contrasting rock types of the beds above and below it (figs. 8, 9).

\section{AGE}

The only organic remains found to date in the Lytle formation in the northern Front Range foothills are chertified fragments of coniferous wood. No fossils

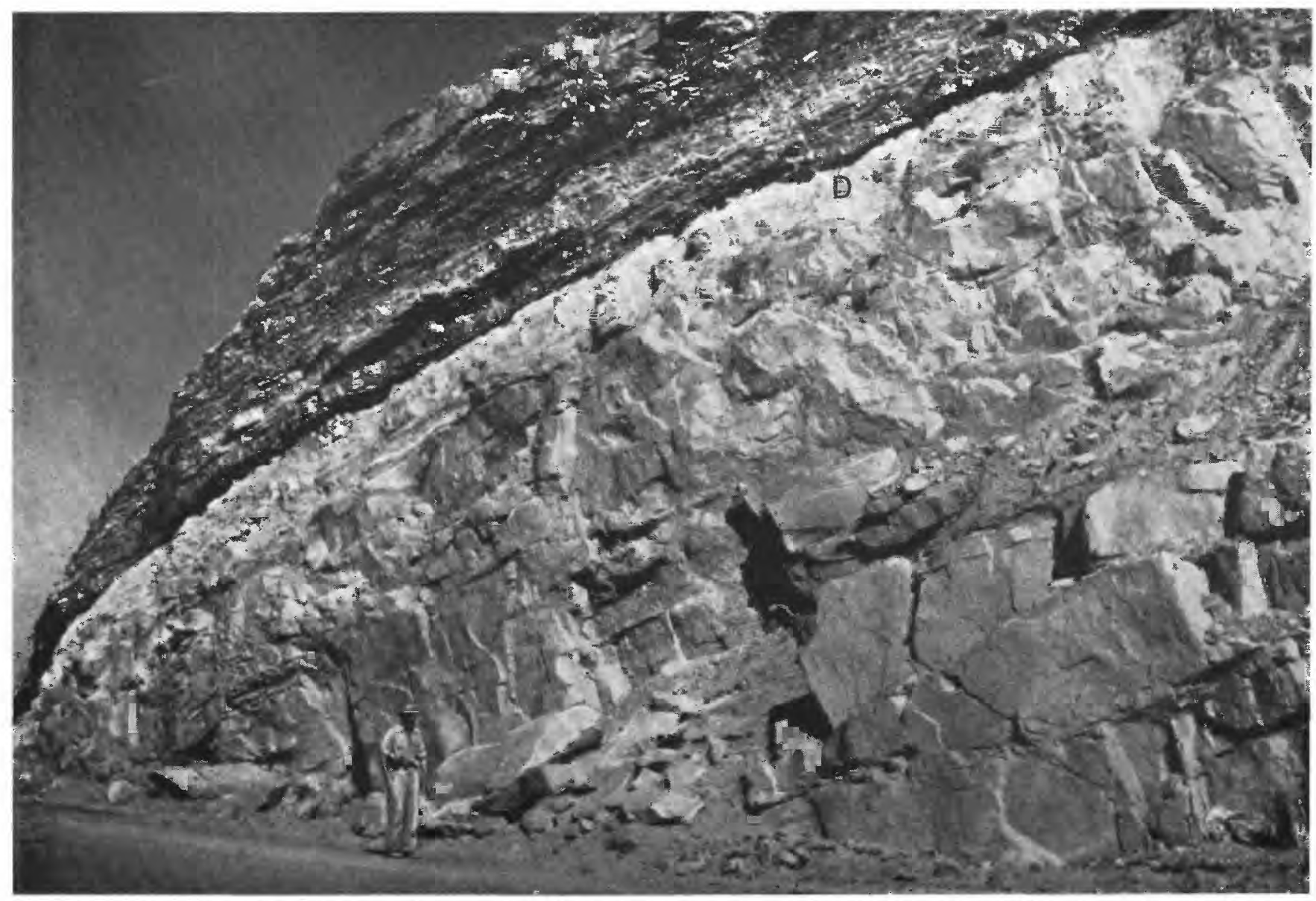

FICURE 8- Tabular sandstone of the Plainview sandstone member of the South Platte formation (above) in disconformable contact ( $D$ ) with massive light-colored sandstone and claystone of the Lytle formation at Spring Canyon dam site, Fort Collins quadrangle. 


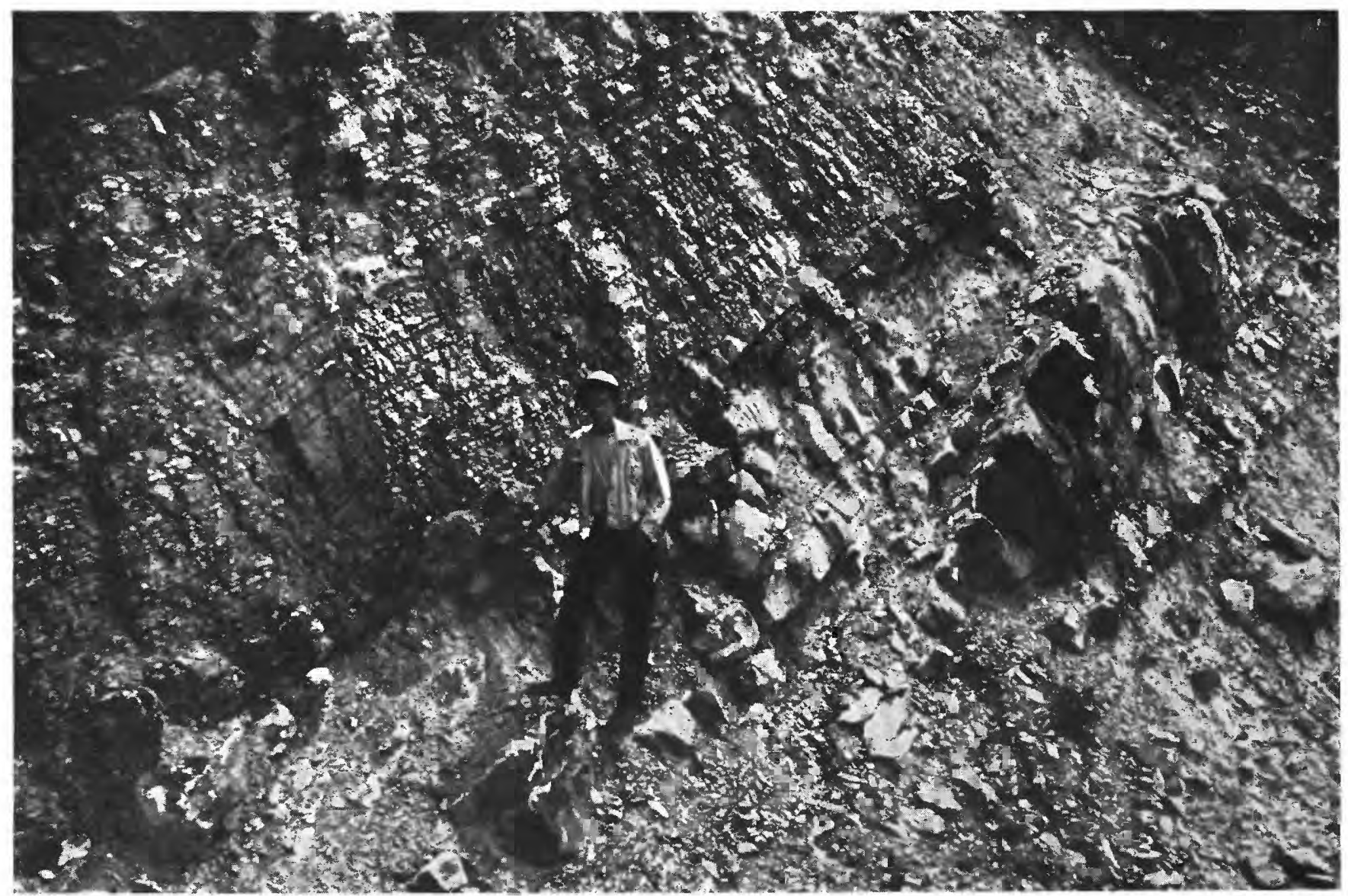

FIgURE 9.- Silty shale and basal sandstone of the Plainview sandstone member of the South Platte formation in disconformable contact (at man's hand) with argillaceous sandstone of the underlying $\mathbf{L y t l e}$ formation on hogback south of Eldorado Springs.

have been described from equivalents of the Lytle in eastern Colorado, but beds in a similar stratigraphic position in Wyoming (Cloverly formation in part) locally contain a sparse assemblage of fresh-water mollusks and charophytes which are considered (Yen, 1946 and 1951; Peck, 1941) Early Cretaceous in age. The mollusks and the charophytes are distinct from similar fossils in undoubted Morrison strata. On the basis of its physical correlation with fossiliferous beds in Wyoming the Lytle formation is classified as Early Cretaceous.

\section{SOUTH PLATTE FORMATION DEFINITION}

The upper part of the pre-Benton Cretaceous sequence, lying between the Lytle formation and the Benton shale, is here treated as a single unit in the northern Front Range foothills and named the South Platte formation. It is equivalent to the upper sandstone, upper shale, middle sandstone, and uppermost black shale part of the lower shale of Lee's Dakota group. The South Platte formation grades laterally northward from a dominantly nonmarine clastic phase in the Kassler quadrangle to a dominantly marine shale 332778-55-3 phase in Larimer County, consequently no single exposure is typical for the unit over its entire area of outcrop, and three localities rather than a single locality are necessary as standards for reference. The formation is named for the South Platte River inasmuch as the southernmost of the three standard sections, selected as the type because it shows the maximum number of subunits, is exposed on the north side of the gap made by the river through the Dakota hogback in the Kassler quadrangle, Jefferson County. In addition, the entire outcrop area of the formation in the northern foothills lies within the drainage basin of the South Platte River.

\section{LITHOLOGY}

The South Platte formation consists of 200-350 feet of alternating units of gray to black shale and brownweathering sandstone. The sandstone is chiefly fine grained but coarser fractions are common locally in the nonmarine phase. Individual sandstone units have considerable lateral extent and vary laterally in thickness, nature of bedding, and amount of contained argillaceous matter. Quartzitic sandstone, in the sense that siliceous cement causes the rock to break across the 
grains, is rare and is confined largely to the top of the uppermost massive sandstone bed.

The shale units in the nonmarine phase consist of hard, laminated, noncalcareous, silty shale that is commonly interlaminated or thinly interbedded with siltstone and fine-grained sandstone. Differential thermal analyses of these shale units show that kaolinite is the dominant clay mineral. Some of the shale is relatively silt free and highly refractory. The transition into the marine phase is marked by (1) a change of the dominant clay mineral in the shale units to illite, (2) a decrease in the sand content of most shale units, and (3) the appearance of zones of calcareous shale contain thin beds of fossiliferous silty limestone.

Thin beds of white, yellow, or light-gray claystone presumed to be altered volcanic ash are common in the shale. These beds hold fixed positions relative to other lithic units and some are very useful as key beds inasmuch as they are laterally persistent and can be traced from the nonmarine phase into the marine phase. In the nonmarine phase they are dominantly kaolinitic and rarely exceed 3 inches in thickness; locally they are hard enough to be classed as porcellanite. One bed (the second key marker in fig. 10.) was sampled at intervals from the nonmarine into the marine phase; its dominant clay mineral changed along the strike from kaolinite to montmorillonite.

One thin zone of slightly fossiliferous marine siltstone extends through most of the nonmarine phase and is useful, along with the larger shale and sandstone units and the thin beds of altered volcanic ash, for correlating between the phases of the South Platte formation.

\section{SOUTHERN NONMARINE PHASE}

Exposures of the nonmarine phase of the South Platte formation extend from the south end of the northern foothills in the Kassler quadrangle, Douglas County, northward to about Coal Creek in the Ralston Buttes quadrangle, Jefferson County. Within this area the formation exhibits its maximum number of subunits. No single exposure of the formation shows each subunit in its entirety, either because of stratigraphic variation such as the local thickening of sandstone subunits at the expense of underlying shale subunits, or because of masking by talus and slope wash. The type section of the formation, which is also the standard for the nonmarine phase, is given on a later page. This type section contains all the subdivisions but some of the shale subunits are incomplete. Consequently an annotated composite section, figure 10 , is used for reference in describing the subdivisions of the formation. The descriptions and the annotated graphic section give only those details pertinent to the aims of this paper.

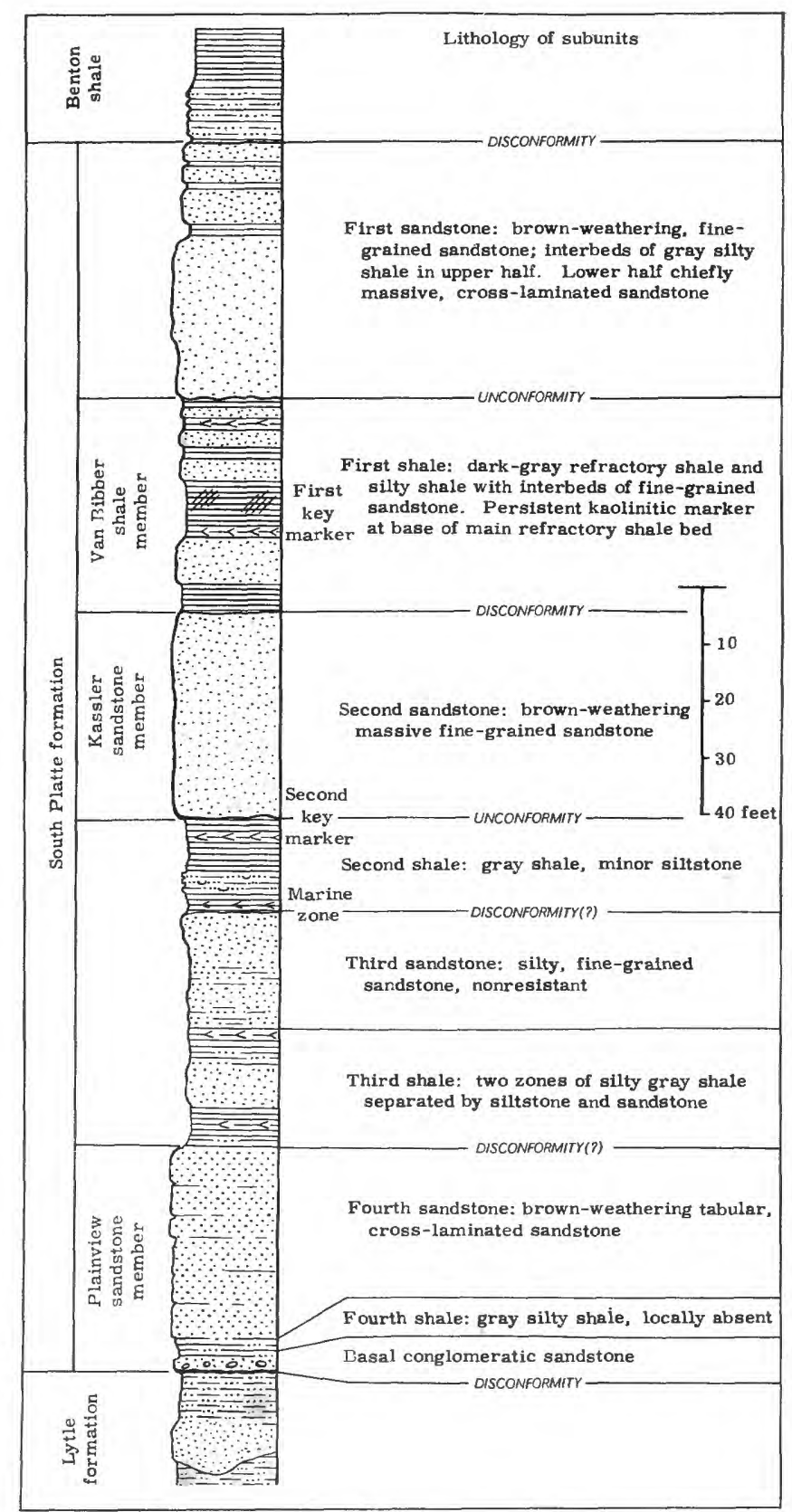

Figure 10.-Composite section of the dominantly nonmarine phase of the South Platte formation.

\section{PLAINVIEW SANDSTONE MEMBER}

The fourth sandstone subunit (fig. 10) at or just above the base of the South Platte formation is a persistent, distinctive unit throughout all phases of the formation in the northern Front Range foothills. This subunit forms a characteristic brown- to rusty brown-weathering ledge of markedly tabular, cross-laminated sandstone. In some places it rests directly on the disconformity at the base of the South Platte formation but commonly it is underlain by a unit of black silty shale (fourth shale of fig. 10) which in turn rests on the thin conglomeratic 
sandstone at the base of the formation. The fourth sandstone subunit and, to simplify mapping, the black shale and basal conglomerate between it and the disconformity at the base of the South Platte formation, are named the Plainview sandstone member for exposures (fig. 11) which occur in the cut of the Denver and Salt Lake Railroad (Moffat Tunnel Route) through the Dakota hogback at Plainview, $\mathrm{NE}_{1 / 4}^{1} \mathrm{NE}^{1 / 4}$ sec. 12, T. 2 S., R. 71 W., Jefferson County. The following section was measured.

\section{Description}

South Platte formation (in part).

8. Sandstone, fine-grained; weathers light gray; and sandy siltstone, thin-bedded, with interbeds of gray plastic silty shale 0.1-0.6 foot thick. Bedding surfaces with ripple marks and worm? castings _.

Plainview sandstone member:

7. Sandstone, fine- to medium-grained, tabular cross-laminated to crossbedded; weathers red brown. Some bedding surfaces ripple-marked. Ridge-forming _.--

6. Sandstone, fine-grained, irregularly thin bedded locally crossbedded, in layers as much as 0.3 foot thick; ferruginous layers weather rusty brown; argillaceous layers weather light gray. Lower 2.2 feet has
South Platte formation (in part)-Continued

Plainview sandstone member-Continued interbeds of fissile gray clay shale. Worm? castings on bedding surfaces ....

5. Sandstone, fine- to medium-grained, tabular cross-laminated and crossbedded in uppermost 2 feet, remainder massive cross-laminated; weathers buff with reddish stain . . . . . . . . . . . . . .

4. Siltstone, gray argillaceous, thin-bedded, with interbeds of shaly siltstone and 1 bed of dark-gray shale 1.5-2.1 feet from top

3. Shale, dark-gray to black, silty with thin interbeds and laminae of light-gray argillaceous siltstone. Local thin concretionary lenses of pyritic silt. Basal 0.8 foot ferruginous sandy siltstone. Worm? castings on silt bedding planes _........
Feet

5. 0
2. Sandstone, light-gray, medium- to coarsegrained and conglomeratic, with scattered chert and quartzite pebbles as much as 0.4 foot in long diameter

Disconformity.

24. 0 Lytle formation (in part):

1. Siltstone and silty claystone, greenish-gray to gray-white with local reddish stain, soft, contains irregular, thin lenses of red-weathering, ferruginous, fine-grained sandstone _..........................

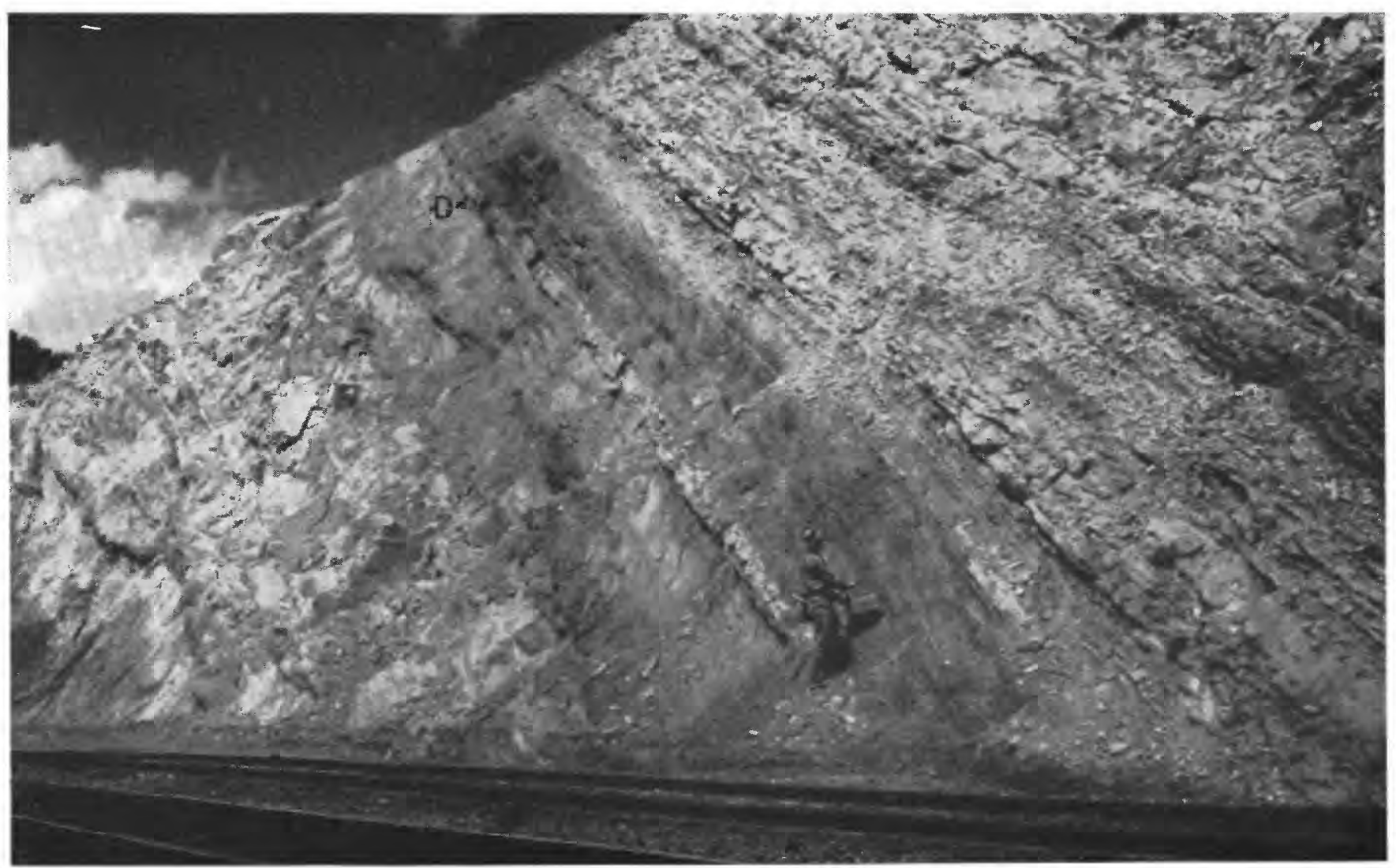

FIGURE 11.-Plainview sandstone member of the South Platte formation (right) and upper part of the Lytle formation (left) in railroad cut atPlainview. Man stands at basal conglomeratic sandstone of Plainview member. $D$, Lytle-South Platte disconformity. 
Units 5-7 comprise the characteristic sandstone part of the Plainview sandstone member. In the type section an 11-foot bed of similar sandstone lies about 5 feet above the top of the member and appears as if it should be included with it. As far as can be determined from outcrops to the north and south, this overlying sandstone is probably part of a locally thickened lens of the third sandstone subunit. Within a distance of 2.3 miles north of Plainview, at Eldorado Springs, this lens reaches a maximum thickness of 65 feet and occupies the position of both the third shale and third sandstone in the area between Coal Creek and Boulder; elsewhere in the northern foothills the distinctive sandstone of the underlying Plainview member is the only ledge-forming unit in the lower part of the South Platte formation.

At many places the shale part of the Plainview sandstone (fig. 8) member is absent and at a few places the basal conglomeratic sandstone is absent. In the road cut along Colorado Route 186 at Spring Canyon dam site, Horsetooth Reservoir, Larimer County, the sandstone portion of the Plainview member rests directly on the surface of disconformity on the Lytle formation.

The Plainview sandstone member is the only subdivision that extends essentially unchanged, except for variation in thickness and shale content, throughout all phases of the South Platte formation in the northern foothills. The Plainview is from 10 to 70 feet thick in the nonmarine phase and has an average thickness of about 30 feet in the northern marine phase, where it forms the western ridge of the familiar double hogback of the Dakota group.

\section{BEDS BETWEEN THE PLAINVIEW AND KASSLER SANDSTONE MEMBERS}

In the nonmarine phase the sequence of beds between the Plainview and the Kassler sandstone members possesses a number of small subunits many of which are laterally persistent. Complete exposures of these beds are rare as they contain few resistant layers and generally underlie wash and grass-covered slopes along the scarp face of the hogback. The single outstanding exception to this is the lens of tabular, cross-laminated sandstone that overlies the Plainview member between Coal Creek and Boulder. For the northern foothills area as a whole, only the details of the uppermost beds, the second shale of figure 10 , are pertinent to this report.

The second shale is commonly exposed, at least in part, under the overhanging ledge formed by the Kassler sandstone member. The shale is dark gray to black and contains in its upper part a prominent bed of altered volcanic ash which is locally as much as 4 inches thick (fig. 12). This bed, the second key marker, is the most per-

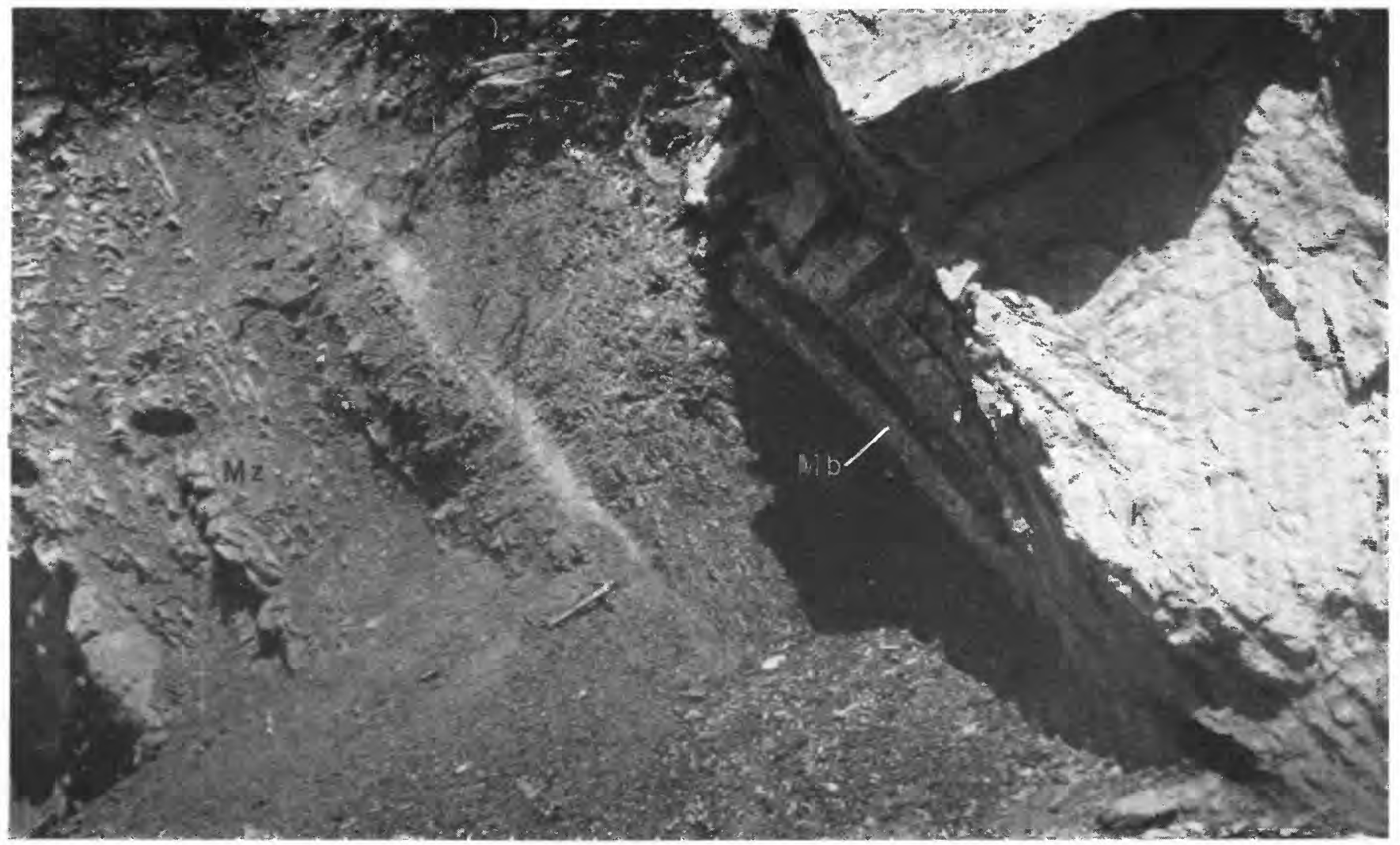

FigURE 12.--Second shale subunit of the South Platte formation, north side of Ralston Reservoir, Ralston Buttes quadrangle. $K$, base Kassler sandstone member; $M b$. second key marker bed; $M z$, platy siltstone of marine zone. 
sistent of all such layers in the South Platte formation and can be followed throughout the northern foothills except in local areas where it was removed by channeling before the deposition of the Kassler member. The lower half of the second shale contains a zone of silty shale interbedded with platy siltstone and fine-grained sandstone which weathers a characteristic orange brown. These platy beds are from 2 to 10 feet thick and locally contain, in about the upper 4 to 10 inches, a sparse scattering of marine fossils the most common of which are Inoceramus comancheanus Cragin and Pteria salinensis White. This is the only marine zone known in the dominantly nonmarine phase of the South Platte formation; it has been found along the hogback as far as 6 miles south of the South Platte River in the Kassler quadrangle. North from Boulder the fossiliferous platy beds become gradually more calcareous and, in the marine phase, they form a conspicuous ledge of platy, fossiliferous, silty limestone that is locally petroliferous (fig. 17).

\section{KASSLER SANDSTONE MEMBER}

Throughout most of the nonmarine phase in the southern part of the northern foothills area the first sandstone subunit at the top of the South Platte formation lies on the dip slope of the hogback and the crest of the hogback is formed by the second sandstone subunit. The latter is the dominant ledge-forming sandstone of the South Platte formation from the Golden quadrangle, where it is about 30 feet thick, south to the Kassler quadrangle, where it is between 75 and 100 feet thick. As it thickens southward, scattered chert and quartzite pebbles appear in its basal part. North of the Golden quadrangle it is too thin to be mapped, but can be traced as far as the Eldorado Springs quadrangle, where it is about 10 feet thick; to the north it appears to grade gradually into marine siltstone and shale.

The second sandstone subunit is here named the Kassler sandstone member for exposures in the Kassler quadrangle. Its type section, at the end of the hogback 0.5 mile north of the South Platte River at Kassler, is a part (units 23-25) of the type section of the South Platte formation given on a subsequent page. Formal recognition of the Kassler sandstone member is warranted, (1) for purposes of correlation with southcentral and southeastern Colorado where it is persistent and widespread, (2) as a map unit of value in delimiting optimum areas for prospecting refractory clay. It is also of value in locating the thin, persistent zone of platy fossiliferous beds a few feet below its base.

\section{VAN BIBBER SHALE MEMBER}

In the nonmarine phase of the South Platte formation most of the refractory shale is contained in a mappable unit lying between the Kassler sandstone member and the first sandstone subunit. This shale unit, which has been the chief source of clay for the refractories industry of the Denver-Golden area since 1865, warrants formal recognition as a unit of economic value and is here named the Van Bibber shale member for exposures in the vicinity of Van Bibber Creek, Golden quadrangle, Jefferson County. No single exposure in this arta shows the entire member clearly. The type section is a composite of adjacent exposures on the scarp of the hogback, between 200 and 500 yards north of Van Bibber Creek; the southernmost of these exposures, showing the main clay bed, is in the airhole of the Golden Fire Brick Co. mine.

\section{Description}

South Platte formation (in part):

22. Sandstone, fine-grained, tabular, in beds 0.5-2.0 feet thick, dense with prominent vertical jointing; weathers buff to brown. Local current ripple marks 0.5 foot between crests on basal surface $-5.0-8.0$

Unconformity.

Van Bibber shale member:

21. Shale, dark-gray, silty, hard, with interbeds of fine-grained shaly sandstone and platy siltstone in uppermost foot; weathers light bluish gray ............

20. Siltstone and fine-grained sandstone, weather, rusty brown, argillaceous.....

19. Shale, dark-gray, hard, silty, locally less silty, semiplastic; weathers light bluish gray. Contains thin kaolinitic graywhite marker bed in middle part .....-

18. Sandstone, fine-grained, argillaceous, irregularly bedded; weathers light gray with rusty stain; upper half with interbeds argillaceous siltstone ............

17. Shale, dark-gray, finely silty, hard; weathers light bluish gray _..........

16. Sandstone, fine-grained, tabular, crosslaminated, in beds $0.4-2.0$ feet thick; weathers buff to brown. Bedding surfaces ripple-marked ...............

15. Shale, as in unit 17 , with thin interbeds, siltstone and fine-grained sandstone in lower part

14. Sandstone, as in unit 16 , in beds as much as 1 foot thick

13. Shale, gray, silty in lower part, refractory, subconchoidal fracture...............

12. Sandstone, rusty-brown, fine-grained, locally ferruginous...................

11. Shale, gray, semiplastic, refractory, subconchoidal fracture; lower 1.5 feet peppered with minute white to yellowish ferruginous ooliths that are locally concentrated in bedding laminae........

10. Shale, gray, stained red and rusty brown; contains concentration of ferruginous ooliths that locally form concretionary structures _... 
South Platte formation (in part)-Continued

Van Bibber shale member-Continued

9. Shale, gray with rusty stain, semiplastic, refractory, with scattered ferruginous ooliths, oolitic laminae and local concretions as much as 3 feet in diameter composed largely of the ooliths.

8 Shale, dark-gray, semiplastic, refractory, with scattered silt laminae

7. Shale, dark-gray, silty with interbeds of rusty brown-stained siltstone in lower part _.

6. Kaolinitic clay, yellowish-white, first key marker bed.....................

5. Siltstone and fine-grained sandstone, gray, weathers light gray with local brown stain. Some interbedded silty claystone, sandstone in upper part, top surface locally ripple-marked .........

4. Shale, dark-gray, silty with interbeds of hard siltstone

3. Siltstone, irregularly thin bedded with sandy and argillaceous layers, hard, locally resistant; weathers light gray with rusty stain.
South Platte formation (in part) - Continued

Van Bibber shale member-Continued

2. Siltstone, probably soft argillaceous. Obscured

Feet

.5

Feet

3. 0

6. 0

.1

Total thickness Van Bibber shale mem-

ber

Kassler sandstone member:

1. Sandstone, fine-grained, locally silty, chiefly irregularly thin bedded to crossbedded, beds $0.3-0.5$ foot thick, locally massive, cross-laminated; weathers gray to brown

Most of the parts of the Van Bibber shale member persist throughout its area of outcrop but vary in thickness. The main shale bed (units 6-15) and, generally,

2. 3 the three thin shale beds above it (units 17, 19, and 21) are refractory; the lower bed (unit 4), here called the

4. 0 lower split, is only locally refractory. The most distinctive beds are the first key marker (unit 6), a persistent white, yellow or light-gray kaolinitic ash bed 3.5 from 2 to 4 inches thick, and the ripple-marked sand-

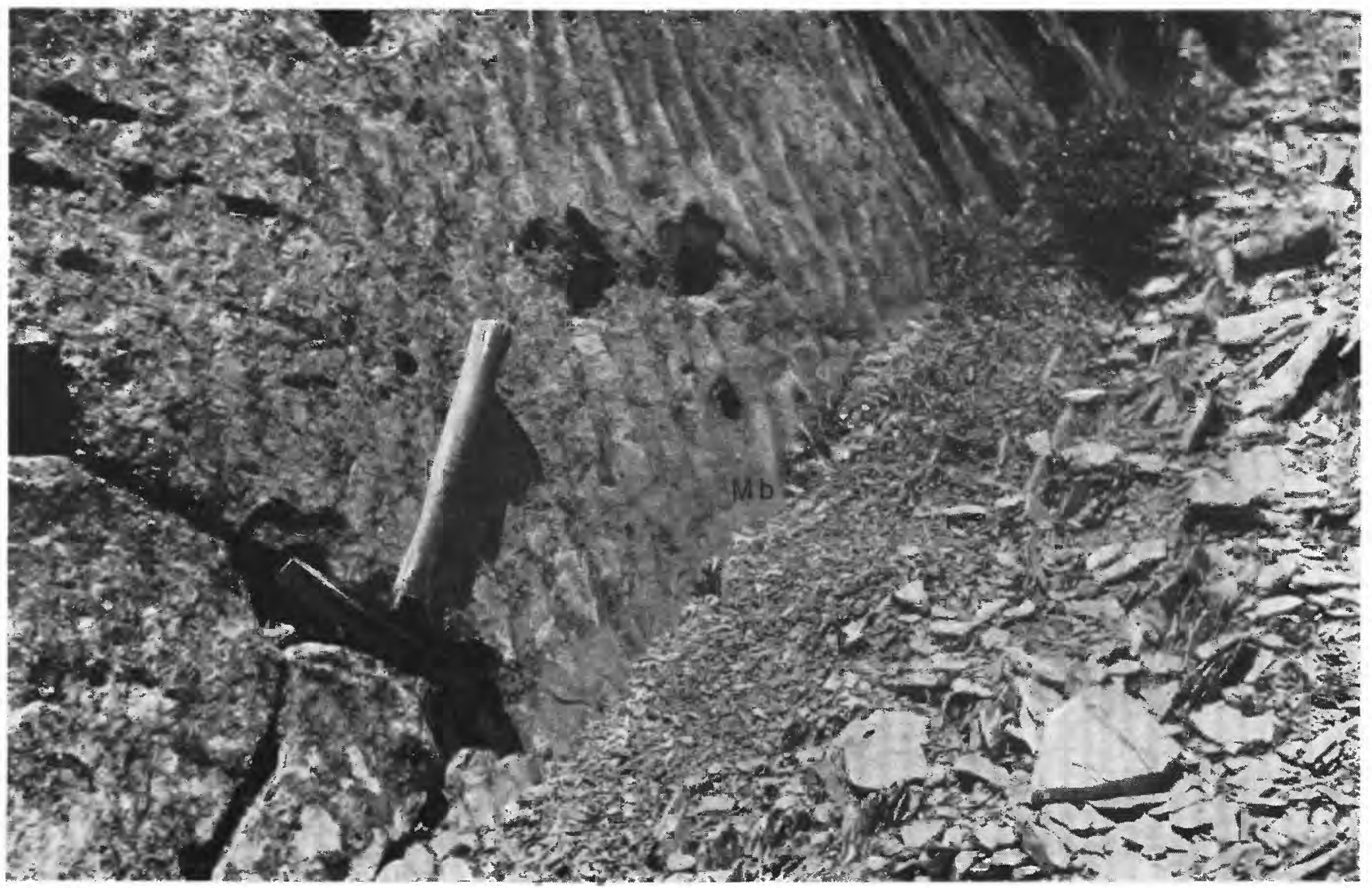

FIGURE 13.-Characteristic exposure of base of main clay bed in the Van Bibber shale member of the South Platte formation. First key marker ( $M b$ ) rests on ripplemarked surface. 
stone (unit 5), a bed of fine-grained sandstone whose indurated upper surface is covered with ripple marks. The first key marker commonly rests directly on the ripple-marked surface, or is separated from it by a few inches of silty shale (fig. 13). The ripple-marked bed and the overlying ash bed serve to identify the main shale bed from the northernmost mines near Coal Creek in the Ralston Buttes quadrangle to the end of the hogback in the Kassler quadrangle. The first key marker can be traced north of Coal Creek and for some distance into the marine phase of the South Platte formation (fig. 17).

The type section of the Van Bibber shale member is the thickest of the many sections measured; more commonly an entire section of the member ranges from 35 to 45 feet thick. The lower contact with the Kassler member is sharp where the lower split or the silty beds beneath it rest directly on the massive sandstone of the Kassler. In areas where the Kassler member is thick the lower split of the Van Bibber member is commonly absent and the ripple-marked sandstone is in contact with the Kassler sandstone.

The upper contact of the Van Bibber member is an unconformity of considerable local relief. Channeling before the deposition of the overlying first sandstone subunit has removed part or all the Van Bibber member over large areas; consequently complete sections of the member are rare.

\section{FIRST SANDSTONE SUBUNIT AND THE BENTON CONTACI}

The first sandstone subunit is the most variable part the South Platte formation in the southern normarine phase. In the Kassler quadrangle this unit is dominantly sandstone and has a fairly persistent shale bed a short distance above the middle. Northward more shale lenses come into the unit but no persistent pattern of parts is discernible other than a general tendency for the thickest sandstone bed to be at the base of the unit. Where this basal sandstone bed is incised deeply into the underlying beds it contains scattered chert and quartzite pebbles in its lower few inches.

Throughout the southern part of the northern foothills area, a zone of platy siltstone and interbedded silty shale from 5 to 20 feet thick lies between the black shale of the Benton and the first bed of brown-weathering, fine-grained sandstone typical of the South Platte formation. The top of the South Platte formation in the nonmarine phase is drawn at the top of this uppermost bed of fine-grained brown-weathering sandstone, and the overlying platy beds are included in the base of the Benton shale. At a number of exposures in the Kassler quadrangle the contact between the platy beds and the underlying sandstone is sharp, and the upper inch of the sandstone bed contains small pebbles and granules of quartzite and chert, which may have been winnowed by current action on a surface of disconformity. This contact, though locally sharp, is not as suggestive of disconformity in other exposures of the nonmarine phase, and on cursory inspection the platy beds appear to be a transition zone in a gradation of beds between the South Platte and Benton formations. It remains to be demonstrated whether a persistent disconformity is actually present at the base of the platy beds throughout the area.

The first sandstone subunit is between 75 and 100 feet thick throughout most of the southern part of the northern foothills. North of Golden this subunit thins appreciably, decreasing to little more than 25 feet in thickness at Eldorado Springs. Here the uppermost of three thin beds of sandstone that compose the subunit is quartzitic and filled with straight and U-shaped tubelike structures probably made by burrowing organisms. The overlying platy transition beds are about 20 feet thick and grade imperceptibly into the Benton shale.

\section{LATERAL VARIATION}

Within the nonmarine phase of the South Platte formation the sandstone subunits, in particular the Kassler sandstone member, thicken southward at the expense of shale subunits, and at the south end of the area, between Willow Creek and Indian Creek in the Kassler quadrangle, the formation consists largely of sandstone and conglomeratic sandstone (fig. 14). Superimposed on this progressive southward thickening and coarsening of the sandstone subunits are many local stratigraphic variations, the most common of which involves the first sandstone subunit and the unconformity at its base. At many places along the hogback, local thick lenses of sandstone in the base of the first sandstone subunit lie in channels cut to different depths in the underlying Van Bibber shale member. This feature accounts in large part for the erratic distribution of refractory shale bodies in the Van Bibber member. Northward from a point slightly more than 1 mile north of the Alameda Parkway the first sandstone subunit rarely thickens at the expense of the Van Bibber member and the refractory shale beds are relatively continuous. South of this point, the first sandstone subunit is characteri ed by massive basal sandstone lenses incised deeply into or through the Van Bibber member and, except for a small area south of the South Platte River, only local pockets of the refractory shale beds remain.

The greatest depth of incision of the channels at the base of the first sandstone unit is in the MorrisonTurkey Creek area. Here the South Platte formation 


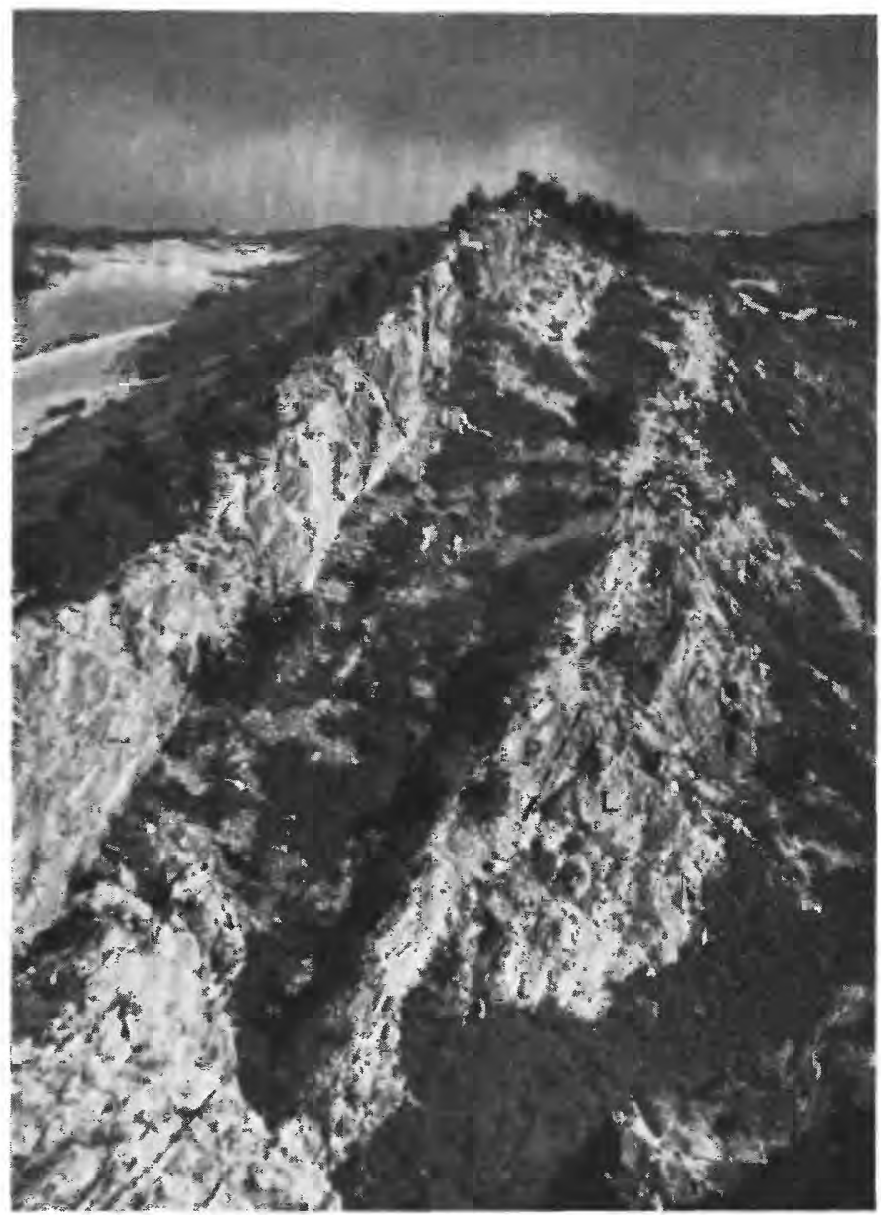

FIGURE 14.-Sandy, nonmarine phase of the South Platte formation south of willow Creek gap, Kassler quadrangle. Upper ledge is Kassler sandstone member, lower ledge contains Plainview sandstone member $(P)$ and Lytle formation $(L)$; saddle between ledges is chiefly in friable third sandstone subunit.

is between 180 and 195 feet thick, its minimum thickness for in the northern foothills. South from the Alameda Parkway the unconformity at the base of the first sandstone subunit gradually transects the Van Bibber member bringing the basal massive sandstone of the first sandstone subunit in contact with the Kassler sandstone member. Within the same distance south from Alameda Parkway, the base of the Kassler member also cuts across underlying beds, consequently much of the underlying second shale subunit is missing. The massive cliff-forming sandstone that forms the crest of the hogback in the Morrison-Turkey Creek area is made up of the coalesced first sandstone subunit and the Kassler member. The reduction in the thickness of the formation is accounted for by the loss of the Van Bibber member and probably all of the second shale subunit. Elsewhere along the hogback to the south, the first sandstone subunit locally coalesces with the Kassler member, but at no place outside the Mor-
rison-Turkey Creek area is the coalesced unit so deeply incised in the underlying beds.

\section{TYPE LOCALITY}

The type exposures of the South Platte formation are in the south end of the hogback on the north side of the gap made by the South Platte River, about 0.5 mile north of Kassler, in the $\mathrm{NE}_{1 / 4}^{1 / 2} \mathrm{NW} / 4 / 4 \mathrm{SE}_{1 / 4}$ sec. 27 , T. 6 S., R. 69 W. A complete pre-Benton Cretaceous section, down to the top of the Morrison, was measured in offset exposures easily joined by tracing key horizons northward along the strike.

\section{Description}

Benton shale not exposed.

South Platte formation:

35. Sandstone, fine-grained, thinly interbedded with siltstone, light-gray with sandy ledges stained rusty brown, platy, locally argillaceous

34. Sandstone, fine-grained, massive, soft, locally pitted surface; weathers light gray with local rusty stain

33. Shale, brown to gray, silty, grading to light-gray argillaceous siltstone

32. Sandstone, fine-grained, massive; weathers brown ..........................

31. Shale, gray and brownish-gray, silty; contains 1 foot argillaceous siltstone at base $\ldots \ldots \ldots$

30. Sandstone, fine-grained, massive- to thinbedded, laminated to cross-laminated, interbedded with light-gray friable siltstone; weathers brown

29. Sandstone, fine- to medium-grained, tabular, cross-laminated to crossbedded; weathers gray; basal 3 or 4 feet contain scattered clay pellets................

Uncomformity.

Van Bibber shale member:

28. Shale, gray, plastic to irregularly bedded siltstone and finegrained sandstone

26. Shale, gray, plastic with $0.1-0.4$ foot of ferruginous clay at top _... $0.4-0.7$

25. Sandstone, fine-grained, platy, locally silty, grades to argillaceous siltstone; weathers light gray with brown stain.-

24. Kaolinitic marker bed, porcellanitic, locally ferruginous in upper 0.3 foot.....

23. Sandstone, fine-grained, massive, with rusty-brown, ferruginous cap and ripple-marked upper surface; weathers gray to brown......................

22. Sandstone, fine-grained, even-bedded, in beds $0.1-2.0$ feet thick, locally laminated; weathers light gray; contains partings and thin interbeds of gray shaly siltstone chiefly in upper 2 feet...- 
South Platte formation-Continued

Disconformity?

Kassler sandstone member:

21. Sandstone, fine- to medium-grained, irregularly thin bedded, cross-laminated to crossbedded; weathers gray; some zones intraformational, clay-pellet conglomerate in lower part.

20. Sandstone, medium- to coarse-grained, massive, cross-laminated, friable; weathers gray to light gray. Contains many clay pellets and few small chert pebbles throughout

19. Sandstone, fine- to coarse-grained, thinbedded, crossbedded; weathers gray. Contains 0.2 foot of chert and quartzite pebble conglomerate at base

Base Kassler member.

Unconformity.

18. Sandstone, fine-grained, thinly interbedded with argillaceous siltstone; weathers brown, platy hard; contains some silty gray shale at top.........

17. Siltstone, gray, argillaceous; and silty shale

16. Sandstone as in unit 18 , contains basal brown-weathering bed about 1 foot thick. Rarely contains fossils.

Inoceramus bellvuensis Reeside

15. Shale, dark-gray, silty, with interbeds of argillaceous siltstone. Upper 1.5 feet is siltstone

14. Sandstone, fine-grained, irregularly thin bedded, becoming progressively more friable and silty downward; weathers light gray with rusty stain in upper part. Upper 1-2 feet indurated ferruginous cap

13. Sandstone, fine-grained irregularly bedded, locally ledge-forming; weathers light gray_

12. Kaolinitic marker bed, light-gray to graywhite, clay, locally shaly, silty in lower 0.7 foot. Thin layer ferruginous siltstone 0.1 foot from top

11. Siltstone and fine-grained sandstone, soft, friable, locally argillaceous; top $0.6-0.8$ foot is resistant, locally ledge-forming -

10. Sandstone, fine-grained, massive, surface pitted; weathers rusty brown .........

9. Siltstone, argillaceous and carbonaceous laminae, soft; weathers mottled gray and brown

8. Shale, gray to black, silty, with thin interbeds of rusty-stained silt, partially obscured. Basal foot is chiefly siltstone with shale partings

Plainview sandstone member:

7. Sandstone, fine-grained, tabular, crosslaminated, silty partings in upper 6.0 feet; weathers light brown with local rusty stain

6. Sandstone, fine-grained, irregularly bedded, friable; weathers light gray with rustybrown streaks.

South Platte formation-Continued

Plainview sandstone member-Continued

5. Siltstone, gray, argillaceous, shaly in lower part containing 1 foot plastic paper-thin shale at base

4. Sandstone, fine-grained, tabular, crosslaminated to crossbedded; weathers light gray to yellow brown. Basal 2 feet contain scattered small clay fragments

3. Siltstone and fine-grained sandstone, gray, platy to shaly, locally argillaceous, interbedded with silty gray shale .......

2. Sandstone, fine- to coarse-grained, massive, with chert, quartzite and claystone pebbles throughout; weathers light gray

Total thickness South Platte formation

Disconformity.

Lytle formation (in part):

1. 9

1. Siltstone grading downward to fine-grained sandstone, yellow with red stain in sandy part, argillaceous

The type section does not show the Benton shale contact clearly, but this contact can be seen on the south 4. 9 side of the South Platte River near the adit to an old clay mine on the east side of the hogback. Missing from the type section is about the upper half to two5. 4 thirds of the Van Bibber shale member, including the main refractory shale. The kaolinitic marker bed (unit 24) and the ripple-marked sandstone beneath it (unit 23) are clearly exposed and serve to identify what remains of the member. The Kassler sandstone mem-

14.8 ber, for which this exposure is also the type, is 72 feet thick. The intraformational clay-pellet conglomerate

1. 5 zones in units $20-21$ are typical of the member throughout the Kassler quadrangle and are also common as far north as the south half of the Indian Hills quadrangle. The base of the Kassler sandstone member is marked

1. 5 not only by the thin chert and quartzite pebble conglomerate of unit 19 , but also by peculiar vermiform

11. 4 ridges on the undersurface of the bed formed by the

filling of irregular depressions in the surface of the underlying beds.

Beneath the Kassler sandstone member the upper

8. 3 part of the second shale subunit, containing the second marker, is missing and the Kassler member rests directly on the platy beds in the lower part of the subunit. Fossils in the platy beds are rare and fragmental.

Unit 14 marks the top of the third sandstone subunit; it grades downward into the third shale subunit and, because the latter is becoming increasingly sandy 17. 2 southward, is not locally separable from it.

The Plainview sandstone member is about 56 feet 6. 4 thick and consists of two benches of the typical rusty- 
weathering, tabular sandstone and a thin basal conglomeratic sandstone in sharp disconformable contact with the underlying Lytle formation.

\section{INTERMEDIATE PHASE-BOULDER COUNTY}

The pattern of change in the South Platte formation from the nonmarine phase to the marine phase along its narrow band of outcrop is not a simple one. The nonmarine phase extends from the Kassler quadrangle northward through the Ralston Buttes quadrangle to about Coal Creek in the Eldorado Springs quadrangle. Here the aspect of the formation as a whole changes appreciably, owing to the thinning of both the Kassler sandstone member and the first sandstone subunit. In addition there is an abrupt local thickening of both the Plainview sandstone member and the third sandstone subunit north of Coal Creek (fig. 17). As a result of these combined changes the outcrop pattern of the South Platte formation is completely altered in the Eldorado Springs quadrangle; here the Kassler member, and locally the first sandstone subunit, instead of forming the principal hogback, lie in the flat, or form low ridges east of a prominent hogback made by the greatly expanded third sandstone subunit and Plainview member. The thickening of the lower sandstone subunits in the South Platte formation is a local feature, and both subunits regain their typical character and thickness in the vicinity of Boulder.

Between Boulder and the latitude of Lyons the South Platte formation is very poorly exposed, owing to an extreme local thickening of shale units and the lack of resistant sandstone units above the Plainview sandstone member. This sandstone member supports the serrate, uneven Dakota hogback north of Boulder, and the remainder of the South Platte formation lies in the float-covered eastern slope of the hogback. A thin, commonly quartzitic, sandstone at the top of the formation, presumably a continuation of part of the first sandstone subunit of the nonmarine phase, locally forms a low ridge east of the hogback formed by the Plainview member, but throughout much of the outcrop between Boulder and Lyons this quartzitic sandstone is too thin to support more than a low prominence at the foot of the slope.

The nature of the South Platte formation in the Boulder-Lyons area is revealed northeast of Lyons in an exposure on the east flank of Rabbit Mountain just south of Little Thompson Creek. This exposure is selected as the standard section for the South Platte formation in Boulder County, where the formation is in an abnormally thick intermediate phase between the nonmarine phase to the south and the typical marine

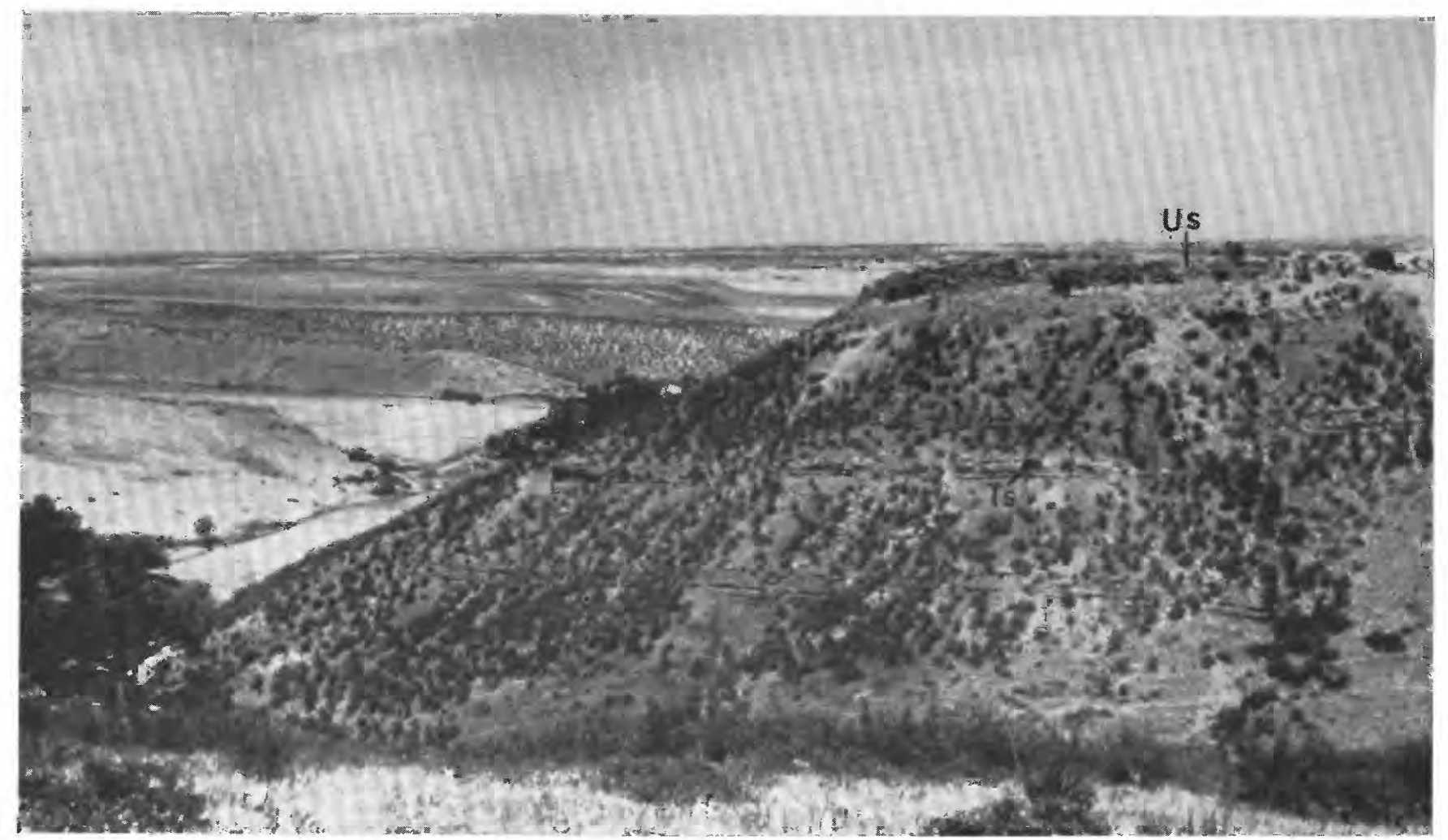

FIGURE 15.-Part of the South Platte formation in the intermediate phase, south of Little Thompson Creek, Loveland quadrangle. Us, beds equivalent to upper sandstone unit and $T s$, beds equivalent to third sandstone subunit. Beds below $T s$ are locally thickened equivalents of third shale subunit. The Plainview sandstone mem-
ber is just out of sight at base of shale slope. 
phase to the north (fig. 15). All the section except the Plainview sandstone member was measured on the west-facing scarp of a local prominence just south of Little Thompson Creek in the $\mathrm{SW} / 4 \mathrm{NW}^{1} / 4$ sec. 2, T. 3 N., R. $70 \mathrm{~W}$. The Plainview member and underlying beds were measured just west of this locality in exposures near the entrance to the Bureau of Reclamation tunnel through Rabbit Mountain.

\section{Description}

Benton shale, not measured.

South Platte formation:

Feet

34. Sandstone, fine- to medium-grained, tabular cross-laminated to crossbedded, quartzitic; weathers brown. Caps prominence above tributary to Little Thompson Creek.

Fish remains.

Halymenites sp...............

Unconformity.

33. Sandstone, platy, irregularly bedded, and gray silty sandstone with interbeds of shaly siltstone and argillaceous sandstone; weathers brown

32. Siltstone, gray, argillaceous, irregularly bedded, local carbonaceous and shaly partings, uppermost foot fine-grained sandstone............

31. Siltstone, argillaceous, and dark-gray silty claystone. At base is 0.1 foot of mixed light-brown silt and bentonitelike clay ..................

30. Sandstone, fine-grained, and argillaceous siltstone; massive to irregularly bedded with shaly carbonaceous partings; weathers to a brownishgray, crumbly, blocky ledge . . .....

29. Siltstone, gray, argillaceous, becoming sandy in upper 8 feet and grading into unit 30. Lower 15 feet contain interbedded shaly siltstone.

28. Siltstone, argillaceous and fine-grained sandstone, weathers orange brown, thin-bodded, locally calcareous. Ledge-forming ..................

27. Siltstone, argillaceous, hard, with blocky fracture . . . ..............

26. Bentonitelike clay, gray, waxy, containing 0.1 foot of dark-gray shale at top...........................

25. Siltstone, as in unit 27 ; upper 0.6 foot forms local ledge....................

24. Bentonitelike clay, gray, waxy, containing 0.1 foot of dark-gray shale

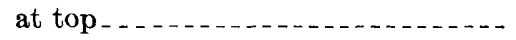

23. Siltstone, gray, argillaceous, thinbedded..........................

22. Sandstone, gray to brownish-gray, fine-grained, thin-bedded, laminated to cross-laminated, interbedded with shaly siltstone and some silty shale. Locally calcareous. Fossils rare _- -
South Platte formation-Continued

21. Shale, dark-gray to black, becoming silty in upper part. Scattered thin beds siltstone and fine-grained sand-

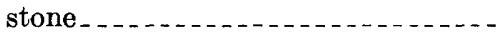

20. Siltstone and fine-grained sandstone, argillaceous, upper 2 feet ledgeforming .......................

19. Sandstone, brownish-gray, silty, irregularly thin-bedded, with argillaceous partings contorted as if disturbed when soft. Forms crumbly ledge - -

18. Siltstone, gray, argillaceous, soft, massive becoming harder and sandier in upper 10 feet. Irregularly bedded, with irregular argillaceous partings in upper part.....................

17. Siltstone, argillaceous, with ledges of hard, thin-bedded, calcareous siltstone in lower 1.9 feet; weathers gray to brown. Calcareous concretions weather orange-brown in zones at top and base of unit............

Feet

9. 0

8. 0

10. 0

30. 0

9.5

16. Siltstone, gray, argillaceous, and silty, gray shale .........

15. Bentonitelike clay, greenish-gray _...-

14. Siltstone in thin, hard beds, slightly calcareous, locally argillaceous; weathers brown ..................

13. Siltstone, gray, argillaceous, soft, irregularly bedded with interbeds dark-gray silty shale in upper part

12. Sandstone, fine-grained, and siltstone, brown-weathering, even - bedded, laminated to cross-laminated, forms blocky ledges broken by softer intercalated argillaceous siltstone and silty shale. Calcareous throughout.

11. Shale, gray, silty, with interbeds, hard, platy, laminated to cross-laminated, tan-weathering, locally calcareous, siltstone increasing in number upward. Some calcareous concretions in upper part. Fossils.

Inoceramus comancheanus Cragin Ostrea noctuensis Reeside

Pleria salinensis White

Ammonite fragment. .........

10. Shale, gray, silty with thin beds and laminae of argillaceous siltstone. Fossils rare.

9. Siltstone, gray, shaly and thin interbeds laminated, silty, fine-grained sandstone. Inoceramus fragments.

8. Shale, dark-gray to black, finely silty, with laminae and thin beds of shaly siltstone in lower half...........

7. Shale, black, hard, fissile, with 0.4-foot bed hard, orange-brown stained siltstone at top._.......

6. Siltstone, hard, ferruginous, irregularly thin bedded, ledge-forming; weathers orange brown .....................
2. 0

.2

16. 5 
South Platte formation-Continued

5. Shale, dark-gray to black, finely silty to very silty, some interbeds shaly siltstone. Upper 3 feet irregularly interbedded carbonaceous shale and siltstone.........................

4. Chiefly shale with thin, hard beds siltstone. Obscured by wash

3. Siltstone and sandstone, gray, argillaceous irregularly bedded, with interbeds of platy gray fine-grained sandstone and gray silty shale. Partially obscured................. Plainview sandstone member:

2. Sandstone, fine-grained, even-bedded, laminated to cross-laminated, in beds rarely more than $\mathbf{1 . 5}$ feet thick; weathers brown. Vertical borings and worm? trails on bedding planes. Some shaly partings and thin beds. Forms east slope of Rabbit Mountain in vicinity

25. $0 \pm$

Total thickness South Platte formation

Disconformity.

Lytle formation:

1. Siltstone, argillaceous, weathers yellow

2. $0-3.0$

Only the Plainview sandstone member and the quartzitic sandstone at the top of the South Platte formation crop out with sufficient regularity along the strike to be traced from the Little Thompson Creek section south through Boulder County to the next complete exposures at Eldorado Springs. The shale and soft, argillaceous sandstone and siltstone beds lying between these resistant sandstones at Little Thompson Creek are difficult to correlate with either the Eldorado Springs exposures to the south or the exposures of the typical marine phase to the north because the lack of outcrop prevents lateral tracing of individual subunits. Nevertheless both the general succession of subunits and the recognition of a few key beds afford a basis for correlating the larger part of the Little Thompson Creek section. The two beds of bentonitelike clay, units 24 and 26 , represent the second key marker, which is commonly split into two or more parts by shale partings throughout the northern foothills. The calcareous, platy sandstone of unit 22 , about 10 feet beneath the bentonitelike clays, is equivalent to the persistent marine $z$ one of the dominantly nonmarine phase. In the Little Thompson Creek section fossil remains in this bed are fragmental, and the preservation of the specimens found in it is too poor to permit specific identification; they include fragments of Inoceramus and a single unidentifiable ammonite fragment. Other recognizable lithic equivalents of subunits in the nonmarine phase are units 18 to 20 inclusive which are correlated with the third sandstone subunit, and units 3 to 18 inclusive which are correlated with the third shale subunit. Within units $3-18$ the three parts of the third shale subunits can be identified.

Above the bentonitelike clays correlated with the second key marker bed, correlation of individual subunits in the Little Thompson Creek section is only tentative. The uppermost quartzitic sandstone, unit 34 , and the sandstone beneath it, unit 33, probably represent the first sandstone subunit of the nonmarine phase. The argillaceous siltstone of units 31-32 may represent the Van Bibber shale member.

The thickening of the South Platte formation in the Little Thompson Creek section, and, presumably, throughout the intermediate phase, takes place beneath the second key marker in beds equivalent to the third sandstone and third shale subunits. A trend toward this is observed in the northern part of the nonmarine phase in which the third sandstone subunit thickens abruptly northward in the Eldorado Springs quadrangle, reaching 65 feet in thickness at Eldorado Springs. Presumably this sandstone becomes argillaceous and silty northward in Boulder County, and decreases somewhat in thickness. Consequently the thickening of the third shale subunit, which is little more than 10 feet thick at Eldorado Springs where the sandstone subunits above and below it almost coalesce, is largely responsible for the abrupt local thickening of the formation in Boulder County. Accompanying this abrupt northward thickening of the third shale subunit is its change to a marine shale bearing the Inoceramus comancheanus fauna.

That part of the South Platte formation above the second key marker is much thinner in Boulder County than in the nonmarine phase to the south, but again this change is gradual and begins in the northern part of the nonmarine phase with the northward thinning of the Kassler sandstone member and the first sandstone subunit.

\section{NORTHERN MARINE PHASE}

Between the exposure on Little Thompson Creek and an outcrop 9 miles, airline, to the north in Handy Ditch on the south side of Dry Creek, Loveland quadrangle, the South Platte formation decreases 100 feet in thickness. This decrease takes place in the shaly beds below the second key marker bed; the beds above this marker increase 30 feet in thickness between the two localities.

From Handy Ditch north to the Wyoming State line the South Platte formation consistently ranges from 230 to 250 feet in thickness and is in its typical marine phase. Exposures north of Boxelder Creek in Larimer 
County are selected as the standard for the marine phase of the formation. The measured section given below was pieced from exposures $0.25-0.5$ mile north of Boxelder Creek in the W/2 $\mathrm{NE}_{1 / 4}^{1 / 25}$ sec. 9, T. $10 \mathrm{~N}$., R. $69 \mathrm{~W}$., Larimer County. This is approximately the same locality described by Lee (1927, p. 39) about 2 miles east of Greenacre Ranch along Boxelder Creek.

\section{Description}

Benton shale, obscured by slope wash.

South Platte formation:

33. Sandstone, fine-grained, quartzitic, hard; weathers brown

32. Sandstone, light-gray with local rustybrown stain, fine-grained, in massive beds $0.6-2.0$ feet thick, cross-laminated, soft to friable

Feet

31. Sandstone, as in unit 32 , but hard and resistant, forms hogback . . . . . . . . . . Unconformity.

30. Siltstone, crumbly argillaceous, locally capped by lens of hard fine-grained sandstone; weathering olive brown. Partially obscured

29. Sandstone interbedded with siltstone, platy to shaly, locally calcareous; some sandy shale, weathers light olive brown

28. Siltstone, platy, to shaly, calcareous, with thin interbeds of silty to sandy, petroliferous, crystalline limestone and partings of silty shale. Fossiliferous.

Inoceramus comancheanus Cragin

Ostrea larimerensis Reeside

Fish scales and bones.............

27. Shale, gray to dark-gray, silty; with two bentonite layers 0.2 foot thick, 2.4 feet and 3.2 feet above base

26. Bentonite

25. Shale, gray, silty with many thin beds and laminae of shaly siltstone. Bentonite bed 0.1 foot thick 4 feet from top....

24. Limestone, gray, silty to sandy, crystalline, petroliferous; weathers tan; contains interbeds of dark-gray to black shale. Fossiliferous.

Inoceramus comancheanus Cragin bellvuensis Reeside

Ostrea larimerensis Reeside noctuensis Reeside

23. Shale, dark- oray to black

22. Limestone and shale, fossiliferous, as in unit 24

21. Shale, dark-gray to black, hard, with scattered thin layers of siltstone that weather with yellow-brown to red ferruginous stain. Bentonite 0.2 foot

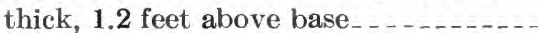

20. Bentonite

19. Shale, dark-gray to black with a few silt laminae

2. 0
South Platte formation-Continued

18. Siltstone, gray, argillaceous and silty gray shale, irregularly thin bedded, weathers light gray and brown. Zone of large, barren ironstone concretions 9 feet above base.

17. Shale, dark-gray to black, fissile, scattered thin beds and laminae of silt in upper part; weathers bluish gray ......

16. Shale, dark-gray to black, weathers fissile; thin zones with interlaminated silt, weathers rusty brown; argillaceous siltstone 1 foot thick at top

15. Siltstone, shaly, ferruginous; weathers rusty brown, contains local ironstone concretions

Feet

23. 5

14. Shale, as in unit 16 , with scattered silt laminae and a thin bed of siltstone 4 feet above base

13. Ironstone concretionary layer

12. Shale, gray to dark-gray with scattered interbeds of olive-gray siltstone

11. Siltstone, olive-gray and silty, gray to dark-gray shale. Zones of ironstone concretions in lower 1.5 feet and 3 feet above base. Bones in siltstone at top of bed.

Plesiosaur vertebrae

10. Siltstone, platy to shaly; weathers buff to dark brown, locally ledge-forming .....

9. Siltstone, platy to shaly and interbedded silty shale; weathers light gray and buff_

Plainview sandstone member:

8. Sandstone, fine-grained, medium- to thinbedded, cross-laminated; weathers brown. Contains some thin zones and partings of sandy shale. Forms second Dakota hogback. Measurement, on dip slope, is approximate............

7. Argillaceous wash, sandy. Obscured ...

6. Sandstone, light-gray, fine- to mediumgrained, massive, cross-laminated; weathers buff to brown

Disconformity.

Lytle formation (in part):

1. Claystone, sandy, with zones of argillaceous sandstone; weathers gray white
12. 4

4. 5 and light gray mottled pink and yellow. Partially wash-covered. Sandstone layers commonly ferruginous and weather brick red. .................. 


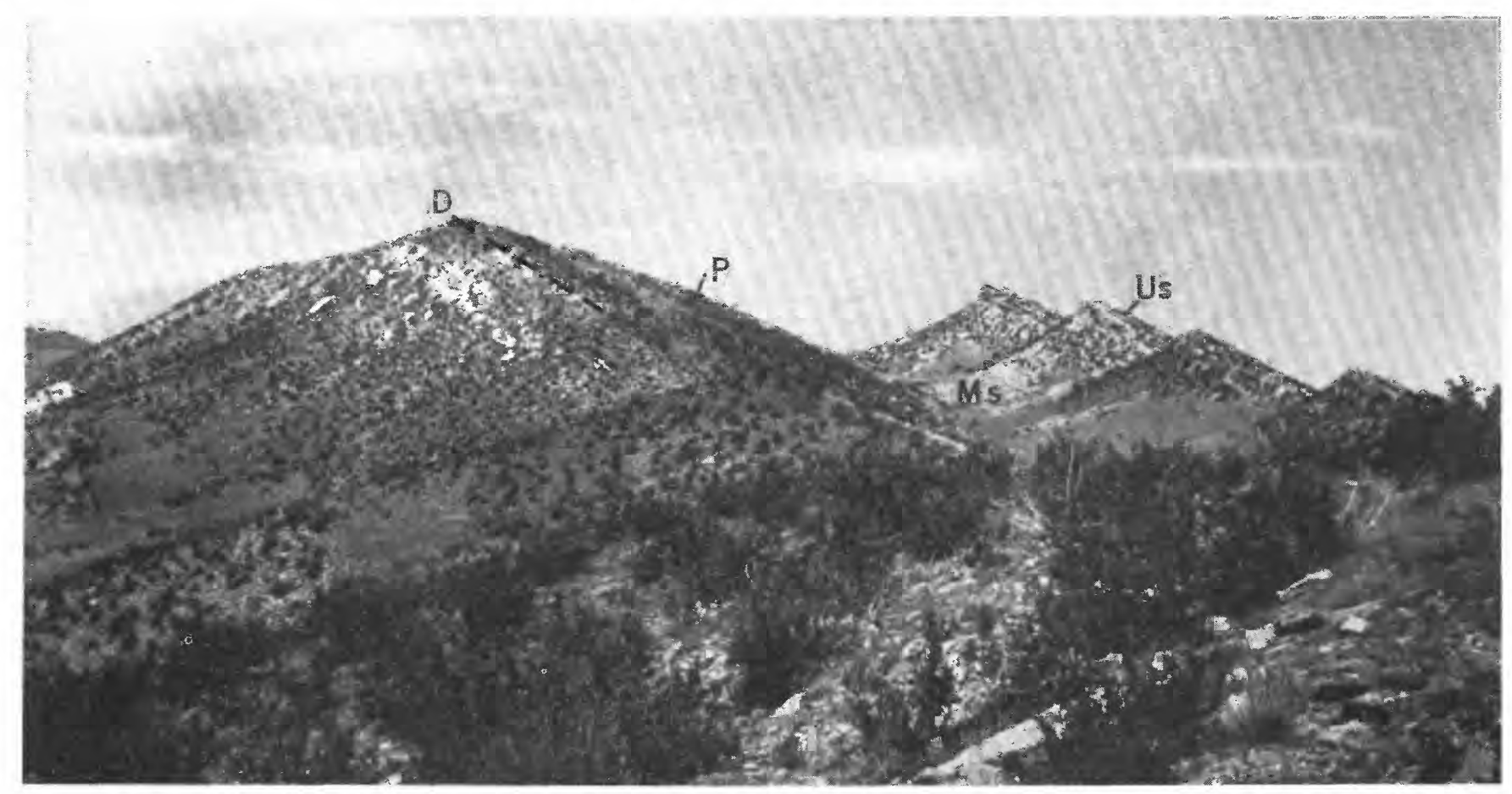

Figure 16. - Typical double hogback formed by marine phase of the South Platte formation near Boxelder Creek, Larimer County. Upper sandstone (Us) forms hogback to right, Plainview sandstone member $(P)$ holds dip slope of hogback to left, marine shale $(M s)$ lies between. Light-colored sandstone lens in Lytle formation lies in slope below Lytle-South Platte contact $(D)$.

The Boxelder Creek section is typical of the marine phase of the South Platte formation throughout most of Larimer County (fig. 16). The chief characteristics are the hogback-forming sandstone subunits at the top and base of the formation and the thick intermediate shale which contains, in its upper third, two benches of silty fossiliferous limestone, both bearing the Inoceramus comancheanus fauna, and which generally lacks invertebrate macrofossils in the lower two-thirds. Scattered foraminifera in the lower part of the shale and the plesiosaur bones at its base indicate that the entire shaly part of the formation is marine. Bentonite beds (units 25, 26, and 27) between the fossiliferous limestone benches are equivalent to the second key marker, and the lower limestone bench (units 22-24) is equivalent to the platy fossiliferous siltstone zone of the nonmarine phase.

The Plainview sandstone member of the Boxelder Creek section is somewhat atypical for most of the marine phase in that it contains some shale and a basal conglomerate beneath the tabular sandstone, which is its chief constituent. Elsewhere in the marine phase the tabular sandstone commonly rests directly on the plane of disconformity at the top of the underlying Lytle formation. This type of contact can be seen in Lee's Bellvue section, at the exposures in Handy Ditch, and at the Spring Canyon dam site on Horsetooth Reservoir.
The equivalent of the third shale subunit (units 9-17) is thinned appreciably, compared with its thickness in the intermediate phase at the Little Thompson Creek exposures; together with a silty zone (unit 18) probably equivalent to the third sandstone subunit, it constitutes a little less than one-half the middle shaly part of the formation.

The fossiliferous limestone layers are found only in the marine phase. Southward in Larimer County they grade into calcareous siltstone at about the latitude of Loveland. The limestone beds are characterized by their coarse texture, abundant disseminated fish remains and oily odor on fresh breaks. Some beds contain abundant remains of the fossils of the Inoceramus comancheanus fauna.

The sandstone at the top of the marine phase of the South Platte formation consists of more than one bed. The uppermost bed, unit 33, is quartzitic and is apparently continuous with the uppermost sandstone of the intermediate phase. The massive cross-laminated sandstone beds below it (units 31-32), thicken northward in Larimer County; they rest unconformably on a zone of interbedded siltstone and sandstone containing the Inoceramus comancheanus fauna.

AGE

The most valuable fossils for dating the South Platte formation are the marine mollusks. With one 
exception all of these are associated with the zonal index Inoceramus comancheanus. This small fauna, described by Reeside (1923), consists of the species listed below:

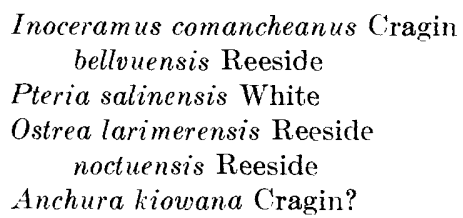

Of these the two species of Inoceramus and Pteria salinensis are the most widespread and are the only species known in the thin marine zone of the dominantly nonmarine phase of the formation. In the marine phase the two oysters are also common. A few ammonite fragments have been found associated with the other mollusks but none are identifiable.

Vertical distribution of the mollusks of the Inoceramus comancheanus fauna in the marine phase of the South Platte formation is controlled by the distribution of the platy siltstone and silty limestone beds to which they apparently are restricted. In the marine phase in northern Larimer County the siltstone and silty limestone layers are confined to the upper third of the argillaceous strata that lie between the Plainview sandstone member and the sandstone beds at the top of the formation. The $I$. comancheanus fauna is correspondingly distributed and thus apparently is restricted to the upper third of the shaly portion of the formation. On the other hand, platy siltstone and calcareous siltstone are more common in the Little Thompson Creek section, occurring as far down in the South Platte formation as beds equivalent to the lower shale part of the third shale subunit. The $I$. comancheanus fauna occurs in these lower platy beds as well as in beds higher in the Little Thompson Creek section. Consequently the entire interval between the Plainview sandstone member and the uppermost sandstone beds of the South Platte formation lies within the $I$. comancheanus zone.

No diagnostic fossils have been found in either the uppermost sandstone of the formation or the Plainview sandstone member. From the upper sandstone near the Boxelder Creek section in Larimer County, Reeside (1923, p. 205) reported a poorly preserved ammonite which he identified as Pachydiscus? sp., stating that

It might well be a specimen of $P$. brazoensis (Shumard), but it might equally well belong to some later species, and even a certain generic assignment must await better material.

The Plainview member locally contains poorly preserved linguloid brachiopods in its lower shaly part.

Plant remains are fairly abundant in some of the subunits of the nonmarine phase of the South Platte formation. Knowlton (1896, p. 466-471) summar- ized what is known of the Dakota flora from the Denver basin and gives a distribution table of the 28 species, most of which were described by Lesquereux (1883, p. 2-107). The table shows that only 11 of the 28 species are present in the Kansas-Nebraska area where the bulk of the fossil plants comprising the Dakota flora were found. The Dakota plants from the Denver area came chiefly from ". . . the hard, white sandstone at Morrison." (Knowlton, 1896, p. 469); this is the Kassler sandstone member of the South Platte formation. The Kassler member contains the most abundant remains of plants in the nonmarine phase but similar plant fossils are also locally common in the shale lenses and, at a few localities, in the sandstone beds of the first sandstone subunit. Inasmuch as the Kassler sandstone member grades laterally into marine shales with Inoceramus comancheanus, its plant remains must be Early Cretaceous in age, and the low correspondence in species between its flora and the supposedly Late Cretaceous flora of Kansas and Nebraska may be indicative of an age difference. Whatever the relationship, too little of an exact nature is known about the Dakota flora to make it of value even for distinguishing between Upper and Lower Cretaceous rocks.

Vertebrate remains from the South Platte formation consist of a few dinosaur tracks, abundant fragmental remains of fish in the silty limestone of the marine phase, and the plesiosaur vertebrae from the Boxelder Creek section. None of these are of value for age determination.

The Inoceramus comancheanus fauna is Early Cretaceous (late Albian) in age; Reeside (1923, p. 196200) points out that it is a depauperate Washita fauna. As no diagnostic fossils have yet been found either in the upper sandstone, above the beds with $I$. comancheanus, or in the Plainview sandstone member below these beds, it is not possible to place the entire formation within this zone. The upper sandstone beds of the marine phase, and the presumably equivalent first sandstone subunit of the nonmarine phase, could be either Early or Late Cretaceous in age. The lowest beds of undoubted Late Cretaceous age carry the early Cenomanian ammonite genus Calycoceras, and lie from 40 to 60 feet above the base of the Benton shale along the east flanks of the Front Range and Wet Mountains. Between the Calycoceras and $I$. comancheanus zones no diagnostic marine invertebrates have been reported from eastern Colorado.

Northward, in eastern Wyoming and the Black Hills region, the Mowry shale overlies the lithic equivalents of the upper sandstone of the South Platte formation, the so-called Muddy sandstone and the Newcastle sandstone. The Newcastle sandstone of the Black 
Hills region contains an Early Cretaceous microfauna (Crowley, 1951) and the Mowry contains the very late Early Cretaceous ammonite genus Neogastroplites (Cobban and Reeside, 1952, p. 1015). The Mowry shale is a northern element in the interior Cretaceous sequence of strata and its exact relation to the section along the Colorado Front Range is not known. It is probably equivalent in part to the interbedded platy siltstone and shale that immediately overlie the South Platte formation and mark the base of the Benton in the northern foothills. That part of the Benton shale between these basal platy beds and the Calycoceras zone may also be equivalent to part of the Mowry; it is largely hard, noncalcareous shale with bentonite beds and, except for undiagnostic pelagic foraminifera, has not yielded marine inventebrates.

Although the dominantly transgressive nature of the South Platte formation and its lithogenetic equivalents elsewhere in the interior region implies a difference in age from place to place, it does not seem likely that the upper sandstone of the formation is appreciably younger than its nearby equivalents in eastern Wyoming. Consequently the entire South Platte formation is here considered to be of Early Cretaceous age.

\section{RELATIONSHIP OF THE PHASES}

Figure 17 shows the correlation of representative sections of the South Platte formation and serves to summarize the changes that take place between its different phases. Correlation from the nonmarine to the marine phase is relatively clear cut between the second key marker bed and the Lytle-South Platte contact. The major changes in this part of the formation have already been mentioned and need no elaboration. Above the second key marker bed it is more difficult to trace individual units because of, (1) the lateral change in facies of the Kassler and Van Bibber members, (2) the variable lithology and thickness of the overlying beds equivalent to the first sandstone subunit, and (3) the variable depths of incision of the channels in which the latter beds were deposited.

The disappearance of the prominent Kassler sandstone member northward is the most conspicuous change in the beds above the second key marker and, for that matter, in the formation as a whole. The gradual northward thinning of the Kassler member continues to about Eldorado Springs, from which point the member becomes increasingly silty and grades, in Boulder County, into a massive argillaceous siltstone between 10 and 25 feet thick. North of Boulder County the siltstone gradually becomes platy and fossiliferous and is interbedded with shale. These platy beds grade, in turn, into calcareous siltstone and silty limestone in northern Larimer County. The overlying Van Bibber shale member loses its identity as its refractory kaolinitic shale changes northward to silty, illitic shale intercalated with platy siltstone, and as the limiting Kassler sandstone member thins out into similar silty and shaly beds.

North of Boulder County the beds equivalent to the first sandstone subunit bear the same relationship to underlying beds as they do in the nonmarine phase, thickening locally at the expense of the underlying beds. Consequently some exposures, like that in Handy Ditch (fig. 17), contain the marine equivalents of the Kassler sandstone and Van Bibber shale members, whereas at other exposures, like that at Boxelder Creek (fig. 17), these beds were eroded before the deposition of the overlying sandstone. The unconformity at the base of the first sandstone subunit and its equivalents is the only unconformity within the South Platte formation that obviously persists throughout the northern foothills.

The narrow band of outcrop of the South Platte formation in the northern foothills is only a single section across the different phases and so is insufficient evidence on which to base more than generalities about the local paleogeography. The gross distribution of the phases of the formation does indicate a positive area south of the center of the Colorado Front Range from which sediments spread northward and northeastward to form the nonmarine phase in Jefferson and Douglas Counties.

A broader perspective is afforded by examining the regional distribution of the sandstone subunits of the South Platte formation. The Plainview sandstone member extends northward from Colorado and is included as part of the Cloverly formation in Wyoming; it is also equivalent, at least in part, to the Fall River sandstone of the Black Hills region. South of the northern Front Range foothills its most conspicuous part, the tabular sandstone that forms the bulk of the member, has not been distinguished in south-central and southeastern Colorado and is either absent or has thinned and become shaly. Apparently the Plainview member is a northern element in the sequence.

The third sandstone subunit probably is a local unit in the nonmarine phase of the South Platte forma. tion, lensing out northward into marine shale and siltstone in Larimer County. Its thickest and most resistant exposures are between Boulder and Coal Creek; it is also more prominent than usual where the South Platte formation as a whole thickens and coarseens in the Kassler quadrangle. In south-central Colorado it may be represented by interbedded silty shale and platy sandstone but it is not a conspicuous unit. 


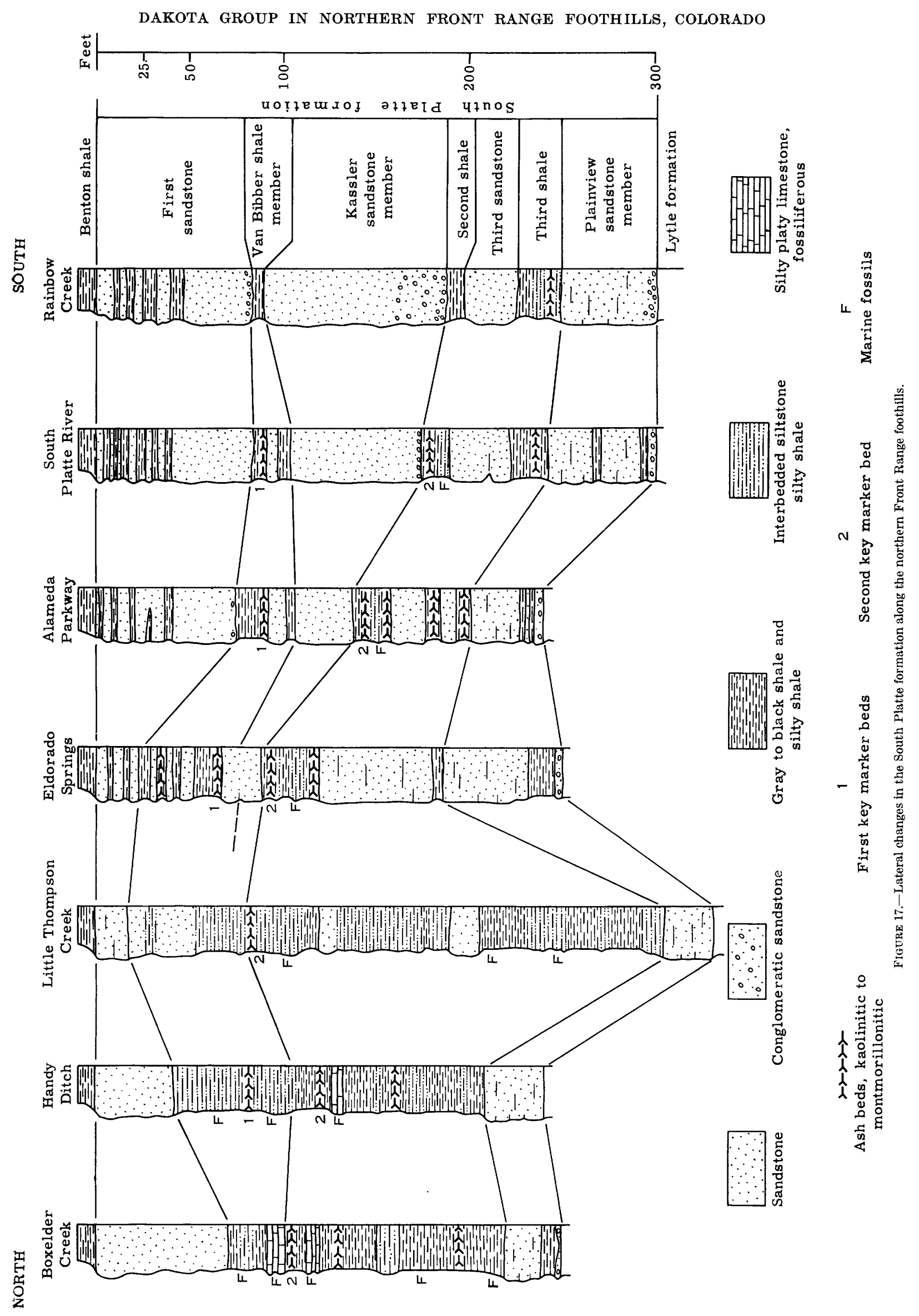


The Kassler sandstone member is a southern element that lenses out northward in the northern foothills. It is widely distributed in south-central and southeastern Colorado where it forms prominent cliffs.

Lithic equivalents of the first sandstone subunit of the South Platte formation are widespread in the interior region (Muddy sandstone member, Dakota sandstone, Newcastle sandstone) where its great variability suggests complications beyond our present knowledge of the stratigraphy. In the southern plains, and foothills of the Rocky Mountains from east-central Colorado soutl and southeastward, this sandstone subunit is a resistant and conspicuous unit. Commonly it coalesces with the equivalent of the Kassler sandstone member below and together these two units form Stose's Dakota sandstone. Locally they are separated by a refractory shale subunit correlative with the Van Bibber shale member.

The change in phase within the South Platte formation in the northern foothills reflects both local and regional events. After an initial sandy transgressive phase (Plainview sandstone member), a marine environment prevailed in much of northeastern Colorado and eastern Wyoming until the withdrawal of the sea marked by the regressive, uppermost sandstone of the sequence. In east-central and southeastern Colorado, however, the sea withdrew earlier as deltas spread eastward and northeastward from local positive areas to form an irregular deltaic plain along what is now the southern Front Range and Wet Mountains. The Kassler sandstone and Van Bibber shale members, and their equivalents, form these deposits. Locally, near the positive areas, nonmarine sedimentation was almost continuous. The nonmarine phase in the northern foothills marks such an area; preliminary studies have revealed other similar nonmarine sequences along the north half of the Wet Mountains. Following the deposition of the marine beds to the north and the sandstone and overlying refractory shales and clays to the south there was a widespread break in sedimentation, presumably caused by slight uplift over a large part of the interior. Subsequently the regressive upper sandstone, which is largely continental in the south and varies locally between marine and continental in the north, was deposited. The overlying platy siltstone and shale at the base of the Benton were deposited on the upper sandstone as the sea readvanced throughout the interior region.

The generalized summary above is based on exposed rocks and so pertains only to the outcrop areas along the mountains in eastern Colorado and Wyoming. Many more details of pre-Benton Cretaceous stratigraphy have been revealed by the subsurface work in the
Denver-Julesburg basin area but little of this information is available. Fogarty ${ }^{1}$ and Hayes ${ }^{2}$ have compiled and interpreted much well data in this area, and their work reveals that the pre-Benton Cretaceous beds thicken eastward from the mountain front into the deeper part of the basin of Early Cretaceous sedimentation. This basin is irregular in shape and lies obliquely northwest across the northeastern part of Colorado. In the deeper part of the basin the subunits increase in number and the stratigraphy is complicated by the addition to the sequence of subunits of eastern provenance, at least one of which apparently lies stratigraphically above the equivalent of the first sandstone subunit of the South Platte formation. The study of the subunits that outcrop in the northern foothills supports the belief generally held that subunits of eastern provenance do not extend to the outcrop along the Front Range in Colorado.

\section{STATUS OF THE TERM DAKOTA GROUP}

Lee's (1923) usage of the term Dakota group in the northern foothills is retained here to include the Lytle and South Platte formations because it is a useful map unit for reconnaissance, or for quadrangle maps of small fractional scale. The relatively thin Lytle formation is difficult to map separately at a scale less than $1: 24,000$ (fig. 18).

The usage follows the original definition of the Dakota group (Meek and Hayden, 1862, p. 419-420) inasmuch as it includes all pre-Benton Cretaceous strata. In the type area along the Missouri River in Nebraska the Dakota rests on Paleozoic rocks so its lower contact is unequivocal. The characteristic twofold lithogenetic division is present in the type area where a sharp break separates sandstone with variegated clay below from sandstone with dark-gray clay, carbonaceous clay, and lignite above. In light of previous attempts to make the name Dakota reflect opinion on the age of the rocks it includes, it must be emphasized that Dakota group, as used here, is strictly a rock term and whether or not the group contains both Lower and Upper Cretaceous rocks, is entirely Lower Cretaceous, or varies in age from region to region, is irrelevant to this definition.

Because of the indefinite nature of the MorrisonLytle contact in parts of the northern foothills it may not be convenient in some places to use the Dakota group as a unit for small-scale mapping; in such places the best map units would be the Morrison and Lytle formations undifferentiated, and the South Platte formation.

\footnotetext{
1 Fogarty, C. H., 1952, Subsurface geology of the Denver basin. Unpublished doctorate thesis in files of Colo. School of Mines.

2 Hayes, J. R., 1950, Crataceous stratigraphy of eastern Colerado. Unpublished doctorate thesis in files of Colo. Univ.
} 


\section{CORRELATION OF THE LYTLE AND SOUTH PLATTE FORMATIONS}

The correlation of the pre-Benton Cretaceous strata in the northern Front Range foothills with equivalent strata in adjacent parts of the interior region is indicated in the chart, figure 19. Correlation with southcentral and southeastern Colorado is based on field work in those areas; for other regions it is based largely on the literature.

The Dakota sandstone of south-central and southeastern Colorado is equivalent to the combined first sandstone subunit, Van Bibber shale member, and Kassler sandstone member of the South Platte formation. The Glencairn shale member of the Purgatoire formation is presumably equivalent to that part of the South Platte formation below the Kassler sandstone member, although it is considerably thinner and the possibility that beds equivalent to the Plainview sandstone member have been at least partially overlapped by the beds in the Inoceramus comancheanus zone cannot be discounted. In and southeast of the Canon City embayment area the $I$. comancheanus fauna is locally present in the top of the Glencairn member. Farther to the southeast on the plains it occurs in silty layers throughout the black shaly part of the Purgatoire. The Lytle formation of the northern foothills is equivalent, by definition, to the Lytle sandstone member of the Purgatoire formation.

The Purgatoire and Dakota terminology is objectionable because it does not conform to the major lithogenetic units within the pre-Benton Cretaceous sequence, and because of its misuse of the name Dakota. The separation of the Dakota sandstone from the Purgatoire formation is not at the most significant break in the sequence, as was supposed when these units were defined, but at a relatively local unconformity. The old idea, based originally on the supposed Late Cretaceous age of the Dakota flora, that this unconformity is the break between Lower and Upper Cretaceous rocks is no longer admissible inasmuch as the unconformity vanishes northward, in the northern foothills, within the $I$. comancheanus zone. The regional disconformity in the sequence lies within the Purgatoire formation, separating it into two lithogenetically distinct parts.

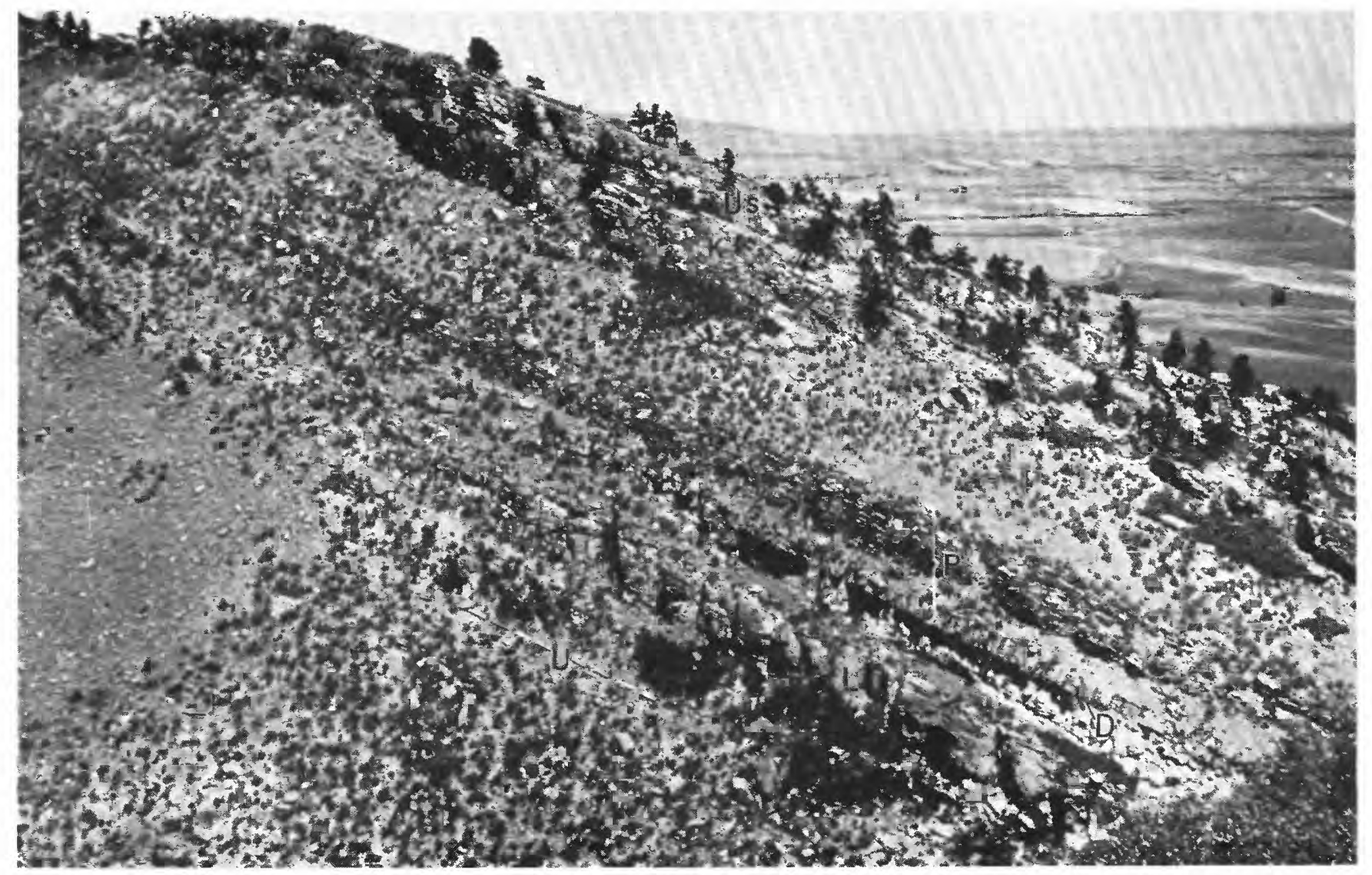

FIGCRE 18.-Characteristic exposure of the Dakota group in the Denrer area. looking north in Dutch Creek gap, Indian Hills quadrangle. Us, upper sandstone subunit; $K$, Kassler sandstone member; and $P$, Plainview sandstone member of South Platte formation. $D$, disconformity between Lytle ( $L$ ) and South Platte formations. $U$, approximate Morrison-Lytle contact. 


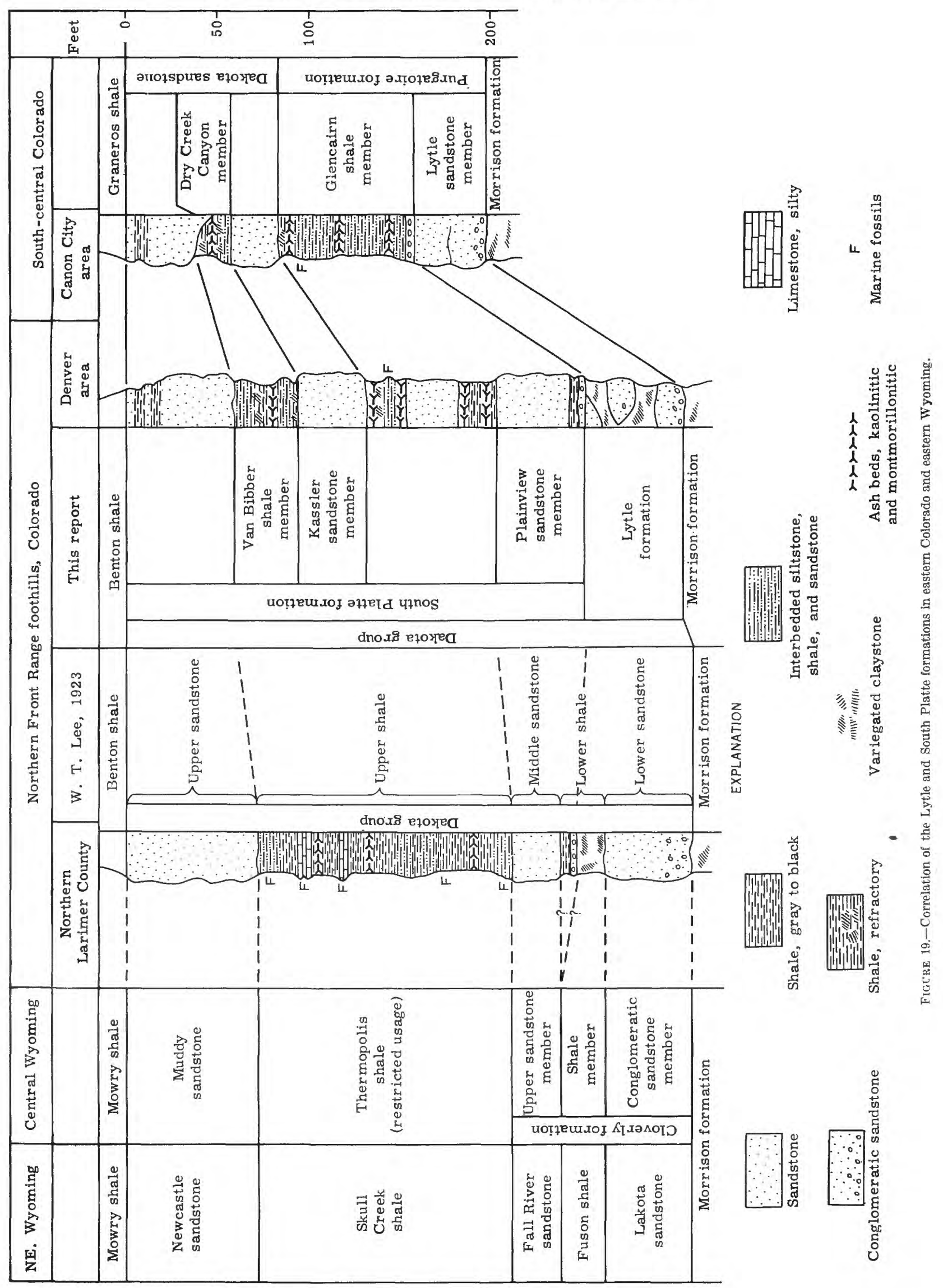


Correlation with the pre-Benton Cretaceous strata of eastern Wyoming largely repeats Lee's work (1923, 1927) and follows the correlation of Lee's Dakota group in the recent Cretaceous correlation chart (Cobban and Reeside, 1952) except for minor adjustments at the position of the disconformity separating the Lytle and South Platte formations. In southeastern Wyoming this disconformity probably lies within the shale member of the Cloverly formation where the latter contains gray or black shale in its upper part. Where the Greybull sandstone member of the Cloverly, or its equivalent sandstone, rests directly on variegated beds or other rocks similar to the Lytle, the disconformity would be at the base of the Greybull. In like manner the disconformity in northeastern Wyoming is probably in the upper part of the Fuson shale where the latter contains gray or black shale in its upper part; in other places it may be at the base of the Fall River sandstone.

\section{EVALUATION OF UNCONFORMITIES}

The upper contact of the Morrison formation is generally accepted as marking the boundary between Jurassic and Cretaceous rocks in the western interior. Recently, Reeside (1952, p. 22-26) summari ed what is known regarding the Morrison and its age in relation to the overlying Lower Cretaceous rocks, concluding that

. . . in the United States there is reason to infer a time interval between the Morrison formation and the succeeding beds that represents possibly part of the Portlandian, probably the Purbeckian, the Berriasian, the Valanginian, the Hauterivian, and possibly the Barremian of the standard European sequence.

However, the interpretation of the magnitude of the hiatus rests largely on the interpretation of the freshwater mollusks, charophytes, and plants that occur in the continental beds lying between the Jurassic (Portlandian) dinosaur-bearing part of the Morrison formation, and the Lower Cretaceous marine beds, such as the South Platte formation, containing the Albian Inoceramus comancheanus fauna. Neither the paleobotanists nor the students of the fresh-water mollusks agree on the interpretation of their separate kinds of fossils, and although most favor an Early Cretaceous age for the beds in question, there is no substantial evidence to indicate what part or parts of the Lower Cretaceous is represented.

The study of the pre-Benton Cretaceous beds in the northern Front Range foothills can add little to the problem of the Jurassic-Cretaceous boundary other than to point out that the gap in time between the Jurassic (Portlandian?) dinosaur-bearing part of the Morrison formation and the Lower Cretaceous (Albian) beds of the South Platte formation is taken up by more than one physical break in the sequence. Three uncon- formities are present in the interval in question: one is at the base of the dominantly red, variegated upper part of the Morrison, the second marks the MorrisonLytle contact, and the third is the disconformity marking the Lytle-South Platte contact. Neither the uppermost part of the Morrison nor the Lytle formation contains diagnostic fossils in the area.

The fresh-water molluscan faunas described from Lower Cretaceous rocks elsewhere in the western interior (Yen, 1949) come from beds that occupy the same stratigraphic position and are lithologically similar to both the upper part of the Morrison formation and the Lytle formation along the Colorado Front Range. Whether these faunas are restricted to beds equivalent to the Lytle part of the sequence or whether they also occur in beds equivalent to the top part of the Morrison is not known. Most authors have considered what is here called the lower part of the Lytle as the basal Cretaceous conglomerate; if rock units so designated could be correlated on the strength of such designation alone, the beds containing the fresh-water mollusks elsewhere would indeed be equivalent to the Lytle along the Front Range. Inasmuch as a single, welldefined, and persistent conglomerate is lacking at the base of the Dakota group along the Front Range, and in other regions as well, no such generalized correlation can be made. Consequently the unconformity at the base of the Lytle could mark either the Jurassic and Cretaceous boundary or a hiatus of unknown magnitude within Lower Cretaceous rocks.

Evidence is equivocal as to what part of the Lower Cretaceous the fresh-water molluscan fauna in question represents. Yen's (1949, p. 469-470) conclusion that the mollusks are older than the British Wealden mollusks and younger than the British Purbeck is not convincing in light of the lack of a physical break between these British units (Arkell, 1933, p. 543). Moreover it has not yet been satisfactorily demonstrated that freshwater mollusks can be used for such precise long-range correlation. Charophytes and ostracods from the beds in question (Peck, 1941) contain elements similar to both Purbeck and Wealden microfossils and have corroborated their Early Cretaceous age. Peck does not attempt a more precise age determination than Early Cretaceous on the basis of these fossils. Dinosaur remains in the same beds have not been studied. If Yen's age determination based on the mollusks is correct and the Lytle formation and its genetic equivalents are basal Lower Cretaceous, the disconformity at the top of the Lytle is probably the larger of the three breaks and represents most of Early Cretaceous time, from early Neocomian to about middle Albian.

The occurrence of more than one obvious physical break in the beds between the Morrison and South 
Platte formations along the northern Front Range in Colorado and the possibility of similar multiple breaks in correlative beds elsewhere in the western interior suggest that more than one Early Cretaceous freshwater molluscan fauna may be present. Yen (1951, p. 3) points out that certain molluscan faunas do suggest at least slight age differences between the Kootenai formation in Montana, the Cloverly formation in Wyoming, and the Peterson limestone in Wyoming and Idaho.

Obviously there is insufficient evidence for evaluating any of the three unconformities between undoubted Jurassic strata and the marine Lower Cretaceous rocks in the northern foothills. If a clear-cut break exists between Jurassic and Cretaceous rocks it could be either the unconformity at the base of the Lytle formation or that at the base of the upper part of the Morrison formation. On the strength of Yen's interpretation of the fresh-water mollusks it is also possible that the disconformity between the Lytle and South Platte formations has the greatest time value of any of the three breaks. In the absence of definitive paleontologic evidence the slight but widespread angular unconformity between the Lytle and Morrison formations seems the most reliable indication of a major time break in the sequence, but this unconformity does not necessarily mark the Jurassic-Cretaceous boundary.

\section{LITERATURE CITED}

Arkell, W. J., 1933, The Jurassic system in Great Britain: 681 p., Oxford, The Clarendon Press.

Cobban, W. A., and Reeside, J. B., Jr., 1952, Correlation of the Cretaceous formations of the western interior of the United States: Geol. Soc. America Bull., v. 63, p. 1011-1044.

Crowley, A. J., 1951, Possible Lower Cretaceous uplifting of Black Hills, Wyoming, and South Dakota: Am. Assoc. Petroleum Geologists Bull., v. 35, no. 1, p. 83-90.

Darton, N. H., 1905, Discovery of the Comanche formation in southeastern Colorado: Science, new ser., v. 22, p. 120. 1906, Geology and underground waters of the Arkansas Valley in eastern Colorado: U. S. Geol. Survey Prof. Paper 52.

Eldridge, G. H., 1896, Mesozoic geology, in Emmons, S. F., Cross, Whitman, and Eldridge, G. H., Geology of the Denver basin in Colorado: U. S. Geol. Survey Mon. 27, p. 51-150.

Finlay, G. I., 1916, Description of the Colorado Springs quadrangle, Colorado: U. S. Geol. Survey Geol. Atlas, folio 203.

George, R. D., 1927, Geology and natural resources of Colorado: Colo. Univ. Sémicentennial Pub., p. 63-64.

Gilbert, G. K., 1897, Description of the Pueblo quadrangle, Colorado: U. S. Geol. Survey Geol. Atlas, folio 36.

Hague, Arnold, 1877, Colorado Range, in Hague, Arnold, and Emmons, S. F., Descriptive geology, U. S. geological exploration of the fortieth parallel (King): Prof. Papers Eng. Dept. U. S. Army, no. 18, v. 2, p. 39-41.
Henderson, Junius, 1909, The foothill formations of northcentral Colorado: Colo. Geol. Survey, 1st Rept., 1908, p. $172-176$.

Hills, R. C., 1899, Description of the Elmoro quadrangle, Colorado: U. S. Geol. Survey Geol. Atlas, folio 58.

1900, Description of the Walsenburg quadrangle, Colorado: U. S. Geol. Survey Geol. Atlas, folio 68.

King, Clarence, 1878, Systematic geology, U. S. geological exploration of the fortieth parallel: Prof. Papers Eng. Dept. U. S. Army, no. 18, v. 1, p. 278-305.

Knowlton, F. H., 1896, The fossil plants of the Denver basin, in Emmons, S. F., Cross, Whitman, and Eldridge, G. H., Geology of the Denver basin in Colorado: U. S. Geol. Survey Mon. 27, p. 466-472.

-1920, A dicotyledonous flora in the type section of the Morrison formation: Am. Jour. Sci., 4th ser., v. 49, p. 189-194.

Lee, W. T., 1920, Type section of the Morrison formation: Am. Jour. Sci., 4th ser., v. 49, p. 183-188.

1923, Continuity of some oil-bearing sands of Colorado and Wyoming: U. S. Geol. Survey Bull. 751-A, p. 1-20. - 1927, Correlation of geologic formations between eastcentral Colorado, central Wyoming, and southern Montana: U. S. Geol. Survey Prof. Paper 149.

LeRoy, L. W., 1946, Stratigraphy of the Golden-Morrison area, Jefferson County, Colo.: Colo. School Mines Quart., v. 41 , no. 2. p. 69-75.

Lesquereux, Leo, 1883, Contributions to the fossil flora of the western territories, pt. 3, The Cretaceous and Tertiary floras: U. S. Geol. Survey Terr., rept. 8, 283 p.

Meek, F. B., and Hayden, F. V., 1862, Descriptions of new Lower Silurian, (Primordial), Jurassic, Cretaceous, and Tertiary fossils, *** : Acad. Nat. Sci. Phila., Proc., v. 13, p. $419-420$.

Peck, R. E., 1941, Lower Cretaceous Rocky Mountain nonmarine microfossils: Jour. Paleontology, v. 15, p. 285-304.

Powell, J. W., 1882, Plan of publication: U. S. Geol. Survey 2d Ann. Rept., p. XL-XLVII.

__ 1890, Conference on map publication: U.S. Geol. Survey 10th Ann. Rept., pt. 1, p. 63-79.

Richardson, G. B., 1915, Description of the Castle Rock quadrangle, Colorado: U. S. Geol. Survey Geol. Atlas, folio 198.

Reeside, J. B., Jr., 1923, The fauna of the so-called Dakota formation of north-central Colorado and its equivalent in southeastern Wyoming: U. S. Geol. Suvey Prof. Paper 131-H, p. 199-208.

1952. Summary of the stratigraphy of the Morrison formation: in Yen, Teng-Chien, Molluscan fauna of the Morrison formation: U. S. Geol. Survey Prof. Paper 233-B, p. 21-51.

Stanton, T. W., 1905, The Morrison formation and its relations with the Comanche series and the Dakota formation: Jour. Geologv, v. 13, p. 654-669.

Stovall, J. W., 1943, Mesozoic stratigraphy, in Schoff, S. L., Geology and ground water resources of Cimarron County, Okla.: Okla. Geol. Survey Bull. 64, p. 43-132.

Stokes, W. L., 1944, Morrison formation and related deposits in and adjacent to the Colorado Plateau: Geol. Soc. America Bull. v. 55, p. 951-992.

Stose, G. W., 1912, Description of the Apishapa quadrangle, Colorado: U. S. Geol. Survey Geol. Atlas, folio 186.

Waagé, K. M., 1952, Clay deposits of the Denver-Golden area, Colo.: Colo. Sci. Soc., Proc., v. 15, no. 9, p. 375-381. 
Waagé, K. M., 1953, Refractory clay deposits of south-central Colorado: U. S. Geol. Survey Bull. 993.

Walcott, C. D., 1903, Nomenclature and classification for the Geologic Atlas of the United States: U. S. Geol. Survey 24th Ann. Rept., p. 21-27.

Waldschmidt, W. A., and LeRoy, L. W., 1944, Reconsideration of the Morrison formation in the type area, Jefferson County, Colo.: Geol. Soc. America Bull. v. 55, p. 10971114.

Wilmarth, M. G., 1938, Lexicon of geologic names of the United States: U. S. Geol. Survey Bull. 896.
Yen, Teng-Chien, 1946, On Lower Cretaceous fresh-water mollusks of Sage Creek, Wyoming: Acad. Nat. Sci. Phila., Notulae Naturae, no. 166.

- 1949, Review of the Lower Cretaceous fresh-water molluscan faunas of North America: Jour. Paleontology, v. 23 , no. 5 , p. $465-472$.

1951, Fresh-water mollusks of Cretaceous age from Montana and Wyoming with a summary by J. B. Reeside, Jr.: U. S. Geol. Survey Prof. Paper 233-A, p. 1-20.

1952, Molluscan fauna of the Morrison formation: U. S. Geol. Survey Prof. Paper 233-B, p. 21-51. 



\section{INDEX}

Page

Acknowledgments

Alameda Parkway, six subdivisions of Morrison along

type section of Morrison

unconformity at base of first sandstone subunit

Anchura kionoana

Area of study

Bellvue section, type locality of Lee's Dakota group.

variegated shale ....

bellvuensis, Inoceramus.

Benton shale.

Bentonitelike clay

Boxelder Creek, stratigraphic section measured at typical marine phase of South Platte at

Calycoceras

Charophytes.

Cloverly formation.

Comanche formation

comancheanus, Inoceramus

Coniferous wood in Lytle.

Correlation of nonmarine and marine phases, South Platte.

Dakota group, history of terminology..

in northern Front Range foothills

Page
15

15

23

23,25

34

41

15,16

24,25

22

41

35,42

38

39

40

41

27

42

31

42

Dakota hogback.

Deer Creek, alternating units of sandstone and claystone at

stratigraphic section measured at.

$16,17,18$

$19,44,45$

$16,24,36$

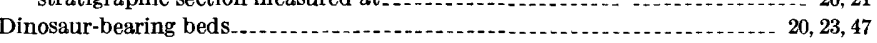

Disconformity within pre-Benton Cretaceous sequence.

between Lytle and South Platte

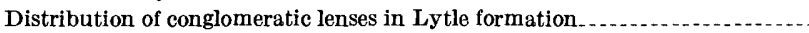

Dry Creek Canyon member.

Eldorado Springs, hogback.

stratigraphic section measured at

First sandstone subunit of South Platte, lithic equivalents. source of fire clay. thickness.

Fossils.

17, 40,41

Fuson shale . . . . . . . . . . . . . . .

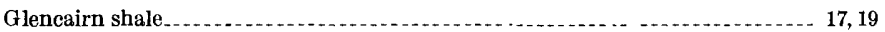

Golden Fire Brick Co. mine 31

Graneros shale

Horsetooth Reservoir, stratigraphic section measured at.

Indian Creek hogback

16
comancheanus 4

distribution

Jurassic-Cretaceous boundary...

47

Kassler sandstone, composition distribution.

thickness.

kiowana, Anchura

Lakota sandstone

larimerensis, Ostrea..

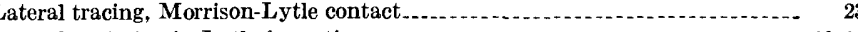

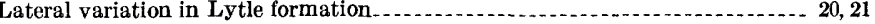

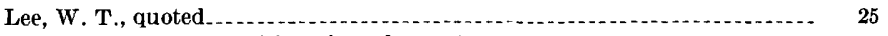

Lytle formation, composition of conglomerate correlation with the pre-Benton Cretaceous.

thickness in Bellvue section

Colorado springs area.

typical locality .

Lytle-South Platte disconformity
Page

Torrison founa composition of

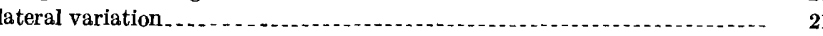
six subdivisions along west Alameda Parkway ..........

Morrison-Dakota contact

Morrison-Lytle contact, interpretation of Eldridge's description of _......... 24, 25

Morrison-Turkey Creek area, base of first sandstone unit..................... contact of Kassler and first sandstone subunit........

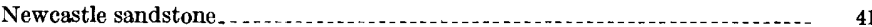

noctuensis, Ostrea

Ostrea larimerensis......................... 41 noctuensis $\ldots$

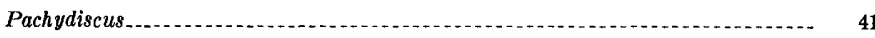

Plainview sandstone, composition.................................... 28, 29

fourth sandstone subunit ..................... 28

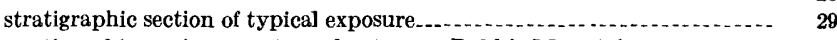
stratigraphic section near tunnel entrance, Rabbit Mountain........... 37

thickness .......... 30,35

Plant-bearing beds . .

Porcellanite

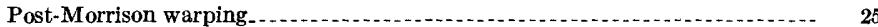

Pre-Benton Cretaceous strata, extent of exposures $\ldots \ldots \ldots, 16$

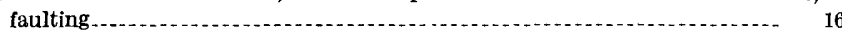

fivefold division $\ldots \ldots \ldots \ldots$

interpretation of twofold lithic division ................................. 18

lithogenetic subunits . .

subdivision in northern Front Range foothills . . .

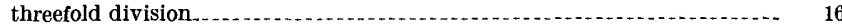

Pteria salinensis . . . . .

Purgatoire formation.

Reeside, J. B., Jr., quoted ...... . . . . . . . . .

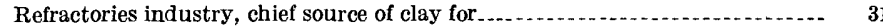

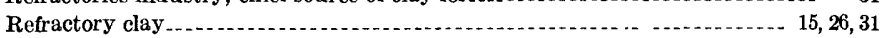

shale, erratic distribution......... 33

in Dakota sandstone

salinensis, Pteria

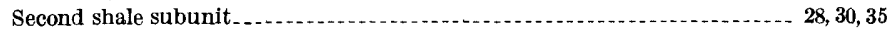

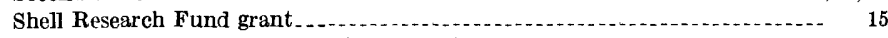

South Platte formation, composition of units

extent of nonmarine phase $\ldots \ldots \ldots$

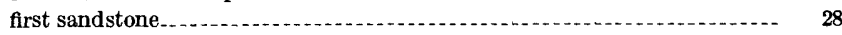

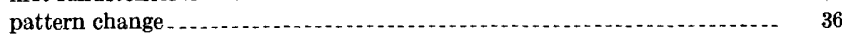

standard section on Rabbit Mountain ................................. 36, 37

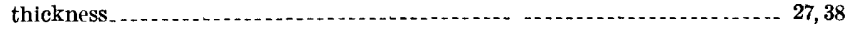

transition of nonmarine phase to marine phase

type section....................................... 34

typical marine phase

Spring Canyon, stratigraphic section measured at . .

Stratigraphic section, across Spring Canyon, Horsetooth Reservoir. .......... 20, 23

between Turkey Creek and Little Turkey Creek ........................... 20

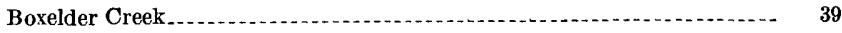

Dakota hogback north of Deer Creek $\ldots$

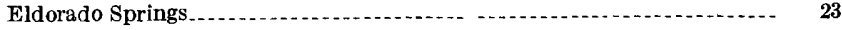

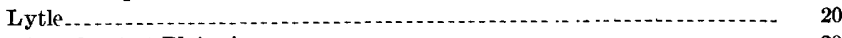

railroad cut at Plainview

Third sandstone subunit _...................................... 28, 30, 38, 40,42

Third shale subunit.

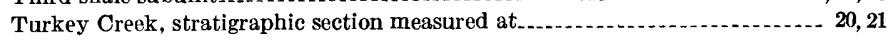

Van Bibber shale, composition.economic value of

first key marker.

thickness

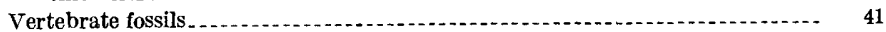

